2020-11-25

\title{
Fishery reforms for the management of non-indigenous species
}

\author{
Kleitou, Periklis
}

http://hdl.handle.net/10026.1/16679

10.1016/j.jenvman.2020.111690

Journal of Environmental Management

Elsevier BV

All content in PEARL is protected by copyright law. Author manuscripts are made available in accordance with publisher policies. Please cite only the published version using the details provided on the item record or document. In the absence of an open licence (e.g. Creative Commons), permissions for further reuse of content should be sought from the publisher or author. 


\section{Fishery Reforms for the Management of Non-Indigenous Species}

Periklis Kleitou ${ }^{1,2^{*}}$, Fabio Crocetta $^{3}$, Sylvaine Giakoumi ${ }^{4}$, Ioannis Giovos ${ }^{2,5}$, Jason M. Hall-Spencer ${ }^{1,6}$, Stefanos Kalogirou ${ }^{7}$, Demetris Kletou ${ }^{2}$, Dimitrios K. Moutopoulos ${ }^{8}$, Siân Rees ${ }^{1}$

${ }^{1}$ School of Biological and Marine Sciences, University of Plymouth PL4 8AA, Plymouth, United Kingdom

${ }^{2}$ Marine \& Environmental Research (MER) Lab Ltd, 202 Amathountos Avenue, Marina Gardens, Block B, Limassol 4533, Cyprus

${ }^{3}$ Department of Integrative Marine Ecology, Stazione Zoologica Anton Dohrn, Villa Comunale, I80121 Napoli, Italy

${ }^{4}$ Centre for Biodiversity and Conservation Science, School of Biological Sciences, The University of Queensland, Brisbane, Queensland, Australia.

${ }^{5}$ iSea, Environmental Organisation for the Preservation of the Aquatic Ecosystems, Thessaloniki, Greece

${ }^{6}$ Shimoda Marine Research Center, University of Tsukuba, Shizuoka 415-0025, Japan

${ }^{7}$ Hellenic Centre for Marine Research, Hydrobiological Station of Rhodes, Rhodes, Greece

${ }^{8}$ Department of Animal Production, Fisheries \& Aquaculture, University of Patras, Mesolonghi, Greece

*Corresponding author, Periklis Kleitou: pkleitou@merresearch.com

Fabio Crocetta: fabio.crocetta@szn.it

Sylvaine Giakoumi: sylvaine.giakoumi1@gmail.com

Ioannis Giovos: ioannis.giovos@isea.com.gr

Jason M. Hall-Spencer: jhall-spencer@plymouth.ac.uk

Stefanos Kalogirou: stefanos.kalogirou@gmail.com

Demetris Kletou: $\underline{\text { dkletou@merresearch.com }}$

Dimitrios K. Moutopoulos: dmoutopo@upatras.gr

Sian Rees: $\underline{\text { sian.rees@ plymouth.ac.uk }}$ 


\begin{abstract}
Marine ecosystems are undergoing major transformations due to the establishment and spread of Non-Indigenous Species (NIS). Some of these organisms have adverse effects, for example by reducing biodiversity and causing ecosystem shifts. Others have upsides, such as benefits to fisheries or replacing lost ecological functions and strengthening biogenic complexity. Stopping the spread of NIS is virtually impossible and so the societal challenge is how to limit the socioeconomic, health, and ecological risks, and sustainably exploit the benefits provided by these organisms. We propose a move away from the notion that NIS have only negative effects, and suggest a turn towards an Ecosystem-Based Fishery Management approach for NIS (EBFM-NIS) in the Mediterranean Sea, the world's most invaded marine region. A structured, iterative, and adaptive framework that considers the range of costs and benefits to ecosystems, ecosystem services, and fisheries is set out to determine whether NIS stocks should be managed using sustainable or unsustainable exploitation. We propose fishery reforms such as multiannual plans, annual catch limits, technical measures for sustainable exploitation, and legitimization of unlimited fishing of selected NIS and introduction of a radical new license for NIS fishing for unsustainable exploitation. Depending on local conditions, investment strategies can be included within the EBFM-NIS framework to protect / enhance natural assets to improve ecosystem resilience against NIS, as well as fishery assets to improve the performance of NIS fisheries. Examples of the former include the enhancement of Marine Protected Areas, harvesting of invasive NIS within MPAs, and protection of overfished predators and key species. Examples of the latter include market promotion and valorisation of NIS products, development of novel NIS products, and innovative/alternative NIS fishing such as fishery-related tourism ('pescatourism'). The application of the suggested EBFM-NIS would create jobs, protect and enhance ecosystem services, and help to meet the United Nations Sustainable Development Goal 14: Conserve and sustainably use the oceans, seas, and marine resources for sustainable development.
\end{abstract}

\title{
Keywords
}

Invasive Alien Species, Ecosystem-based fishery management, Ecosystem services, Capital assets, Marine Protected Areas

\section{Highlights}

- Non-Indigenous Species (NIS) are reshaping Mediterranean marine ecosystems

- Fisheries need to adapt to limit socioeconomic and ecological losses

- Exploitation strategy of each NIS should be based on a cost-benefit analysis

- Policy reforms are proposed for sustainable or unsustainable exploitation strategy

- Investment in natural capital assets and fishery assets is essential 


\section{Introduction}

Non-indigenous species (NIS, also known as alien, exotic, introduced, or non-native species) are species introduced outside of their natural past or present range, and outside of their natural dispersal potential (Pyšek et al., 2009). The introduction and establishment of NIS is recognised as one of the major elements of ongoing anthropogenic global environmental change (Cassey et al., 2018) and their number is increasing worldwide (Seebens et al., 2017). Moderate increases in introductions of NIS are expected to cause major impacts on biodiversity in most global socioecological contexts (Essl et al., 2020).

The Mediterranean Sea is a biodiversity hotspot containing $~ 7 \%$ of the known world marine biodiversity with many endemic and iconic species (Boudouresque, 2004; Coll et al., 2010). This richness has offered valuable ecosystem services and supported human wellbeing for millennia (Theodoropoulou, 2019). However, the Mediterranean basin is threatened by an intensification of human activities and various additional pressures, such as overfishing, eutrophication, habitat loss and climate change, which are impairing the structure, integrity, and functioning of marine ecosystems in the region (Claudet and Fraschetti, 2010; Coll et al., 2010; Lacoue-Labarthe et al., 2016; Liquete et al., 2016). Synergistic effects of these drivers, coupled with increased global marine trade and recent enlargement of the Suez Canal, have rapidly increased the influx of Non-Indigenous Species (NIS) and reshaped local biocommunities (Galil et al., 2018b; Galil et al., 2019).

Invasion of NIS has four main stages: (1) arrival, (2) establishment, (3) dispersal or spreading, and (4) impacts (Kolar and Lodge, 2001). Major pathways for the arrival of NIS in the Mediterranean Sea include 'transport-stowaway' (the transport of species attached to ships, boats, and marine structures) and 'interconnected waterways/basin/seas' (Suez Canal), followed by aquaculture and aquarium trade (Kalogirou, 2011; Katsanevakis et al., 2013; Hulme, 2015; Gewing and Shenkar, 2017). Management policies designed to avoid NIS introductions have only recently started to become widely acknowledged and mandatory (Galil et al., 2018b).

Important advances towards the control of pathways that allow marine species to cross biogeographical barriers include a) the European Union (EU) Regulation 1143/2014 on the prevention and management of the introduction and spread of invasive NIS, b) the enforcement of the Convention for the Control and Management of Ships' Ballast Water and Sediments in 2017 (BWM Convention), and c) the EU Regulation 708/2007 concerning use of alien and locally absent species in aquaculture. Any regulatory measure on the Suez Canal relies on policy coordination between Mediterranean EU and non-EU countries (Galil et al., 2018a). As this joint effort is failing to tackle the introduction of NIS, mainly of Indo-Pacific origin through the canal, and given that early eradication is usually unachievable, efforts in the Mediterranean Sea are mostly focussed on adaptive management, monitoring, and limiting the secondary spread of NIS populations (Giakoumi et al., 2019a). 
Controlling the spread of marine NIS poses a number of challenges, such as incomplete and inaccurate data about species biology and impacts, and lack of concerted action to effectively control propagule pressure (such as eggs and larvae) (Carboneras et al., 2018; Galil et al., 2018a). By the time that NIS impacts are identified, species are typically well-established making management measures costly and eradication impossible. For such reasons, and the fact that the European Commission suggests avoiding disproportionate or excessive costs associated with the application of management measures, Plotosus lineatus (Thunberg, 1787) is the only marine species included on the EU priority list which has 75 terrestrial NIS (EC/2019/1262) (Tsiamis et al., 2020).

A complete halt of marine NIS spread in the Mediterranean Sea is impossible and many species are continuing to spread in the region. In eastern and southern areas of the Mediterranean Sea, tropicalization (an increasing dominance of warm-water species) is happening at a significantly faster rate than in other regions of the world (Last et al., 2011; Cheung et al., 2013), with warm-water species increasing in abundance and expanding northwards, while temperate species decline (Kalogirou et al., 2012; Givan et al., 2018; Azzurro et al., 2019). Climate change may further diminish large-sized native fish populations in the Mediterranean, some of which with commercial interest, while pelagic, thermophilic, and generally NIS of Indo-Pacific origin will be increasingly favoured (Moullec et al., 2019). Many NIS lead to ecosystem shifts and reduce the biodiversity that underpins ecosystem services. However, other NIS can provide benefits to humans by introducing novelty, replacing lost ecological functions, adding redundancy that strengthens resilience, and providing ecosystem services (Chaffin et al., 2016; Sfriso et al., 2020) (Figure 1). In parallel, many NIS have become targets for local fisheries, often helping to stabilize local fisheries catch (Michailidis et al., 2019; van Rijn et al., 2019; Saygu et al., 2020).

\begin{tabular}{|c|c|c|c|}
\hline $\begin{array}{l}\text { Provisioning } \\
\text { Nutrition }\end{array}$ & $\begin{array}{l}\text { New commodities } \\
\text {-New food source for fish } \\
\text {-Novel habitats }\end{array}$ & & $\begin{array}{l}\text { Tositive mechanisms } \\
\text { - Negative mechanisms }\end{array}$ \\
\hline $\begin{array}{l}\text { Water storage } \\
\text { Ornamental and } \\
\text { other materials } \\
\text { Genetic resources }\end{array}$ & $\begin{array}{l}\text { Algal blooms } \\
\text { Degredation of habitats/resources } \\
\text { Competition } \\
\text { Fouling shellfish, gear, equipment } \\
\text { Entanglement in nets } \\
\text { Disease transmission } \\
\text { Clogging intake pipes }\end{array}$ & \multirow{2}{*}{\multicolumn{2}{|c|}{ 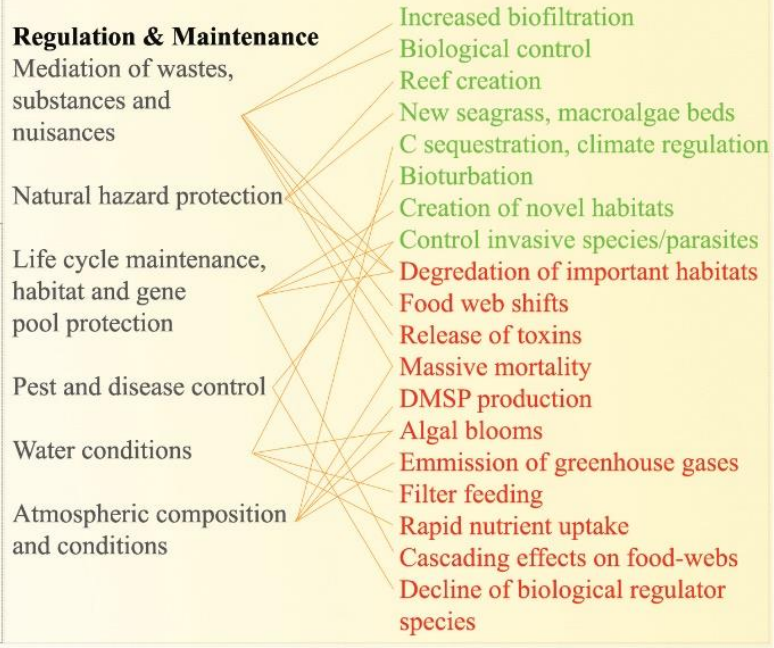 }} \\
\hline $\begin{array}{l}\text { Cultural } \\
\text { Physical and experiential } \\
\text { interaction } \\
\text { Intellectual and } \\
\text { representative interaction } \\
\text { Spiritual, symbolic and other } \\
\text { interactions }\end{array}$ & $\begin{array}{l}\text { Creation of important habitats } \\
\text { Increase opportunities for research } \\
\text { Materials for research } \\
\text { Biomonitor and indicators } \\
\text { Degredation of important habitats } \\
\text { Algae/seagrass washed ashore } \\
\text { Damage of archaelogical sites } \\
\text { Algal blooms } \\
\text { Jellyfish invasions } \\
\text { Injuries } \\
\text { Reduced research possibilities } \\
\text { Interference with long-term } \\
\text { monitoring }\end{array}$ & & \\
\hline
\end{tabular}


Figure 1. Main mechanisms through which marine Non-Indigenous Species (NIS) affect Ecosystem Services. Adapted from Katsanevakis et al. (2014). Examples and details for each mechanism are presented in Katsanevakis et al. (2014). For instance, NIS that cause algal blooms consume nutrients affecting ocean nourishment and consequently water conditions. Moreover, Dimethylsulfoniopropionate (DMSP) is produced by some marine algal NIS. DMSP can be enzymatically converted to the volatile dimethylsulphide (DMS) which could have a cooling effect on climate and help to compensate for warming from "greenhouse effect", but negative effects on air quality.

Society faces the considerable challenge of managing NIS to limit social and ecological damage as the Mediterranean Sea already has more than 600 of these species already established (Zenetos et al., 2017; Giangrande et al., 2020). Here, we suggest the application of a strategy where established NIS can become the target species of a fishery that is managed based on an ecosystem-based approach integrating ecological, economic, and social components.

\section{Ecosystem-Based Fishery Management of Non-Indigenous Species}

To date, NIS management has focused on single species monitoring and mitigation measures, an approach that does not consider the interactions of NIS within the ecosystem. This approach is problematic because it overlooks the fact that some of these species might provide useful ecosystem functions and that several Mediterranean fisheries have become dependent on economic returns from targeting NIS (Corrales et al., 2018; Michailidis et al., 2019).

Ecosystem-based fishery management (EBFM) was developed to move beyond single species management by incorporating ecosystem considerations such as habitat changes, bycatch, and ecosystem and human interactions (Pikitch et al., 2004; Trochta et al., 2018). Levin et al. (2018) define EBFM as "a holistic, place-based framework that seeks to sustain fisheries and other services that humans want and need by maintaining healthy, productive, and resilient fishery systems". Although there is no consensus on the best EBFM implementation and its wider adoption has been slow, EBFM is imperative for sustainable fisheries and livelihoods (Lloret et al., 2018; Marshall et al., 2018; Rees et al., 2020).

In the case of NIS, the application of EBFM can help managers adapt current thinking and practices, and set clear goals and objectives. Not all NIS should be treated the same way, as some may have severe impacts, and others marked benefits. Given the interconnectivity of the Mediterranean, countries that surround this sea would benefit from having a consistent approach to the management of NIS. We propose the development of an Ecosystem Based Fisheries Management strategy for NIS (EBFM-NIS) for Mediterranean countries that will rely on a cost-benefit analysis to determine whether any fishery based on NIS should be managed as:

(i) an established 'sustainable' commercial activity, regulated with catch quotas (where appropriate) and gear restrictions to prevent pressure on local assemblages (Plan A);

(ii) in an 'unsustainable' manner, to facilitate overfishing of NIS populations (Plan B). 
The EBFM-NIS strategy includes the local investment in capital assets (natural, physical, human, financial, and social capital) to increase the environmental and socioeconomic sustainability of NIS fisheries (Figure 2). The investment in capital assets should rely on a supplementary sustainability framework that accounts for the characteristics of each location.

We elaborate on the steps shown in Figure 2, including the decision-making process, and the implementation management measures that can be followed in a structured and iterative process by fostering social knowledge and learning through constant monitoring to improve human well-being and livelihoods (Allen and Garmestani, 2015). 
Exploitation strategy

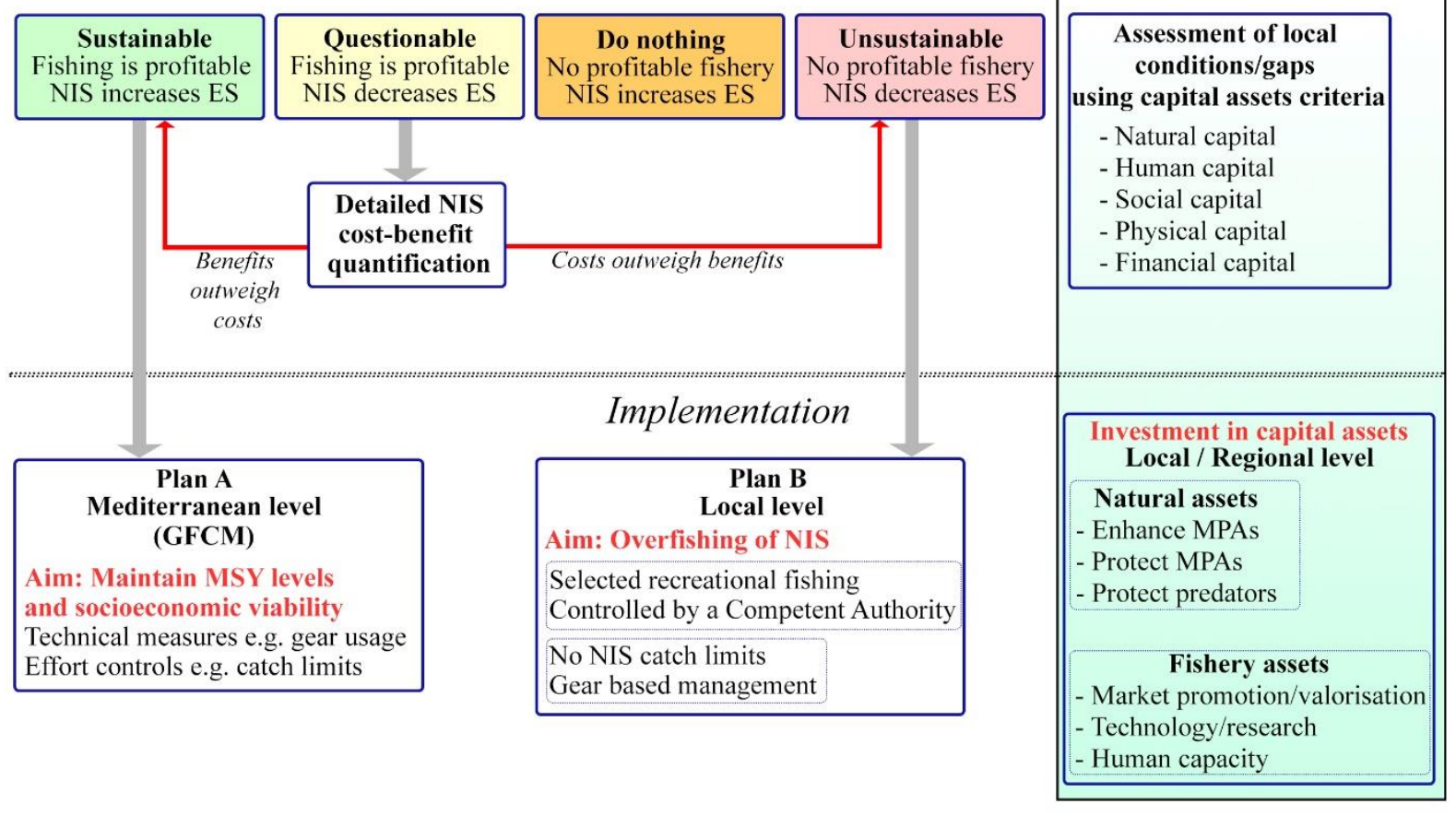

\section{Consequences}

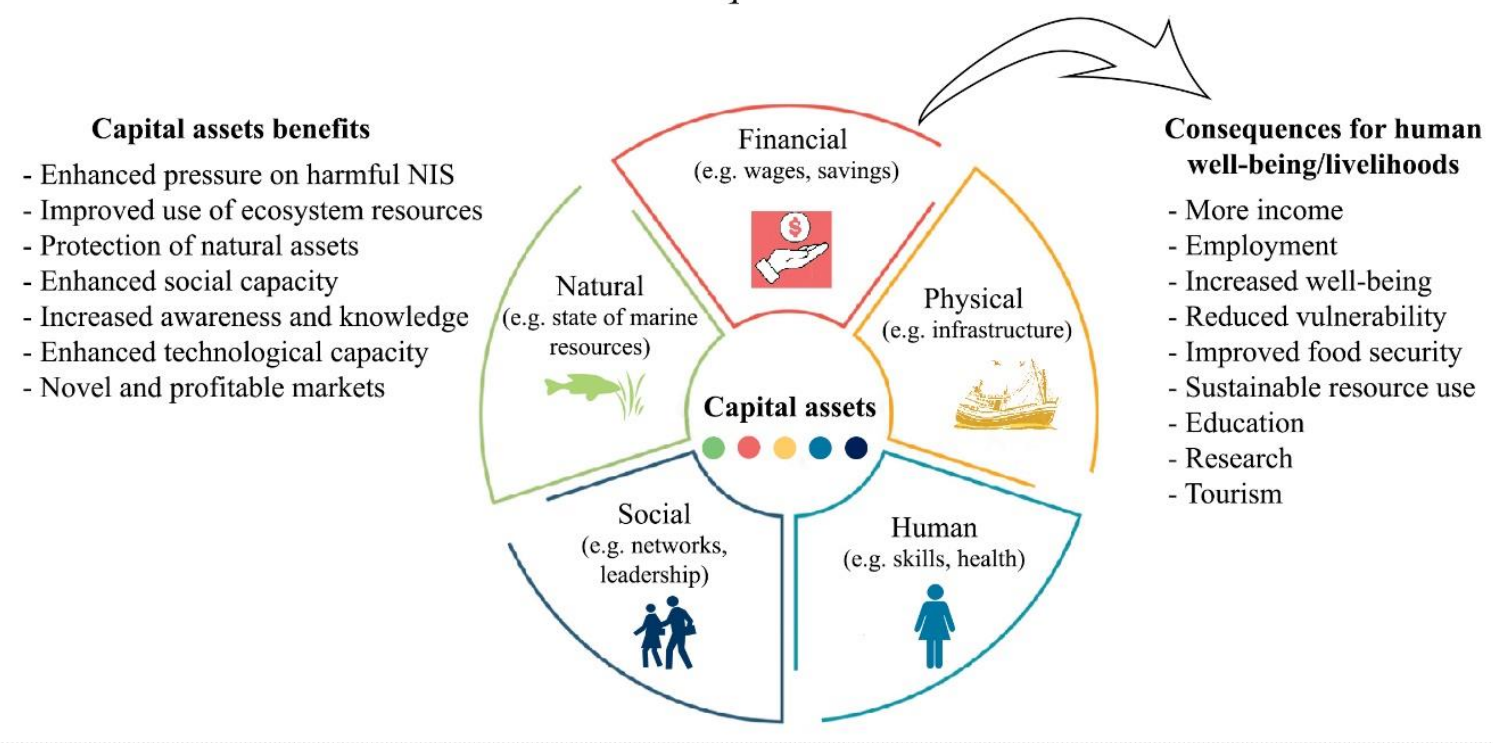

Figure 2. Proposed framework for Ecosystem Based Fishery Management of the Non-Indigenous Species (NIS) in the Mediterranean Sea (ES: Ecosystem Services, GFCM: General Fisheries Commission for the Mediterranean).

\subsection{Policy decision - Guiding NIS fishery directions}

The cost-benefit analysis of the EBFM-NIS should not only consider the environmental and human (social-cultural, economic, and institutional) dimensions from the fishery itself (hereafter referred as 'fishery performance') but should also look at the impacts of the NIS on the invaded environments. Any rare or recently established NIS may be excluded from consideration as their benefits and impacts will 
not be evident. Priority can be given to species which have been established for many years. Our proposed cost-benefit analysis includes a preliminary analysis using a decision matrix, and a detailed structured analysis for 'questionable' species.

A decision matrix can be applied where species impacts are clear and do not require detailed quantification of their costs and benefits (Figure 3). Invasive NIS whose negative impacts clearly outweigh potential socioeconomic benefits should be managed with the aim to prevent impacts on local marine biological assemblages (see Plan B in Fishery Reforms section) and to limit their populations (example species in 'Unsustainable', Figure 3). On the other hand, managers may decide that NIS which cause negative impacts but whose exploitation is beneficial for fisheries could be exploited at levels that maintain their stocks at Maximum Sustainable Yield (MSY) to improve the socio-economic viability of their fisheries (see Plan A in Fishery Reforms section) (example species in 'Sustainable', Figure 3). Many NIS that can/could provide significant benefits for Mediterranean fisheries have been associated with negative impacts on ecosystems (example species in 'Questionable', Figure 3). For those, a detailed quantification considering the full range of costs and benefits to broad ecosystem services should be followed. 


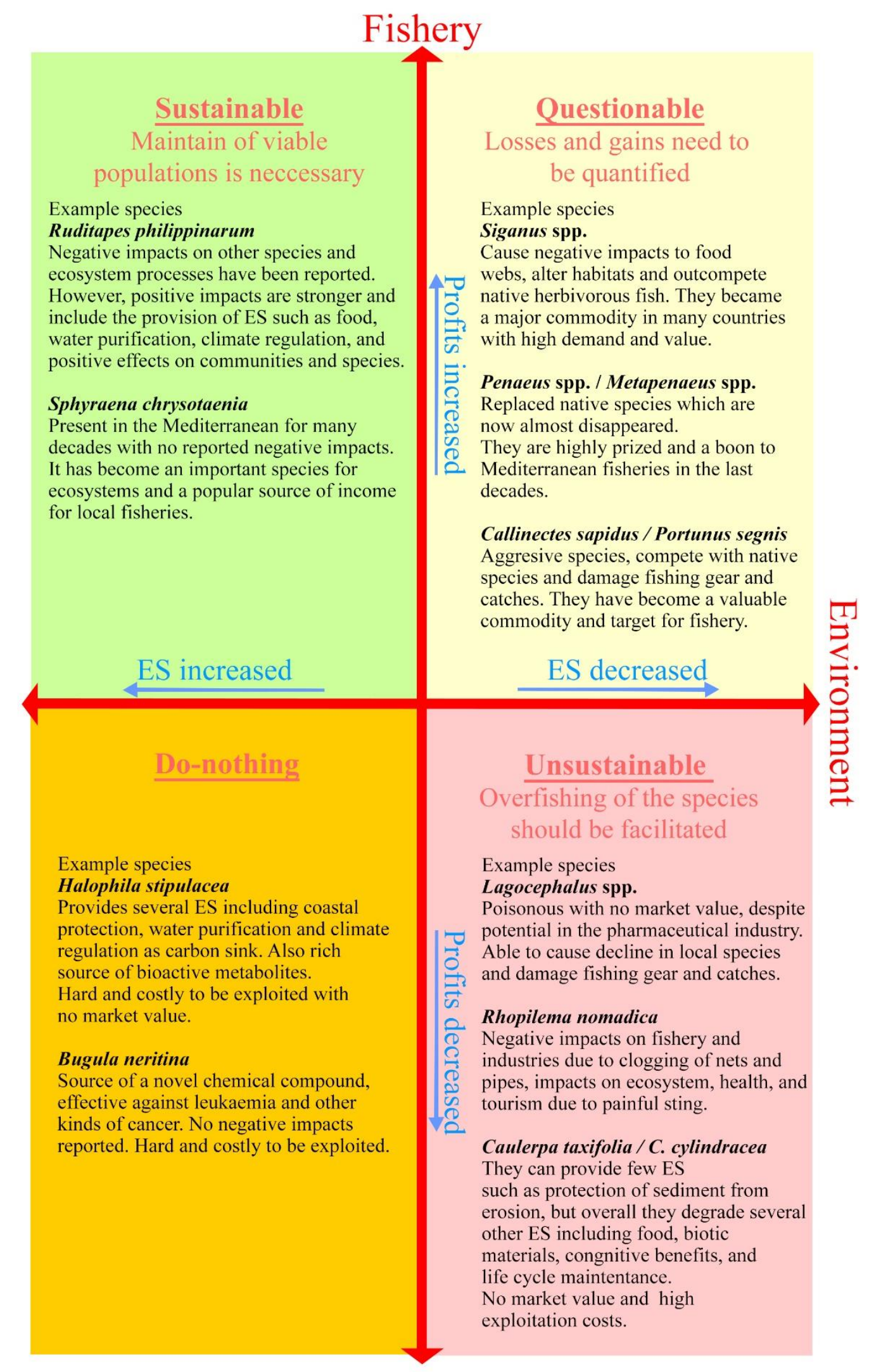

Figure 3. A decision matrix that can be used as a first step to decide an exploitation strategy based on the impacts of Non-Indigenous Species (NIS) on the ecosystem services (ES) and the performance of their fishery (socioeconomic profitability). Profits of fishery are related to fishery \& fleet (e.g. efficiency, catches, and sales), working conditions (e.g. job creation), and environmental (e.g. bycatch and damage to habitats). References for 
species impacts: (Streftaris and Zenetos, 2006; Katsanevakis et al., 2014; Corsini-Foka and Kondylatos, 2015; Kleitou et al., 2018; Apostolaki et al., 2019; Michailidis et al., 2019; Bel Mabrouk et al., 2020; Killi et al., 2020).

Detailed quantification can be complex, particularly for parameters that are difficult to specify in monetary terms, such as impacts of NIS on cultural ecosystem services (Bonanno, 2016). Expert elicitation is a widely-used technique in science to overcome complexity, lack of data, and the urgent/imminent nature of many conservation decisions (Martin et al., 2012; Roy et al., 2020). This approach has been increasingly used in assessments to guide and implement policy making for NIS prioritisation and mitigation in the Mediterranean Sea (e.g. Roy et al., 2015; Bacher et al., 2018; Galanidi et al., 2018; Peyton et al., 2019). However, all previous assessments have been biased towards the negative effects of these species, as (potential) positive effects were often not taken into consideration. Martinez-Cillero et al. (2019) attempt to address these gaps by describing the INvasive Species Effects Assessment Tool (INSEAT) that enables expert elicitation and assessment using an ES framework scale that accounts for the magnitude and reversibility of both positive and negative impacts. In addition, INSEAT allows experts to highlight the level of confidence in each evaluation, thus enabling the identification of research gaps and/or conjectures. We suggest that INSEAT is adapted to include marine ecosystem services (mentioned in Figure 1). Emphasis could be given on the recent NIS history, as impacts reported in the past (e.g. replacement of a native congeneric species) might now be irreversible, with the NIS playing a critical role in maintaining ecological function in a different climate.

Although an important decision tool, expert elicitation is often subject to contextual biases and special precaution should be taken during the assessment processes. Experts might be prone to mistakes due to factors such as overconfidence, representativeness, groupthink, difficulties associated with communicating knowledge in numbers and probabilities, and inappropriate and ill-informed methods (Hemming et al., 2018). Structured techniques to minimize uncertainty, identify experts, capture the level of knowledge, calibrate scores, aggregate experts' judgments, and validate responses, are strongly recommended (e.g. Martin et al., 2012; Colson and Cooke, 2018; Hemming et al., 2018).

To assess NIS fishery performance, several EBFM models have been developed and utilized (e.g. Atlantis, Ecopath with Ecosim, size-spectrum, MICE, Osmose, RAPFISH) (Pitcher and Preikshot, 2001; Plagányi et al., 2014; Hornborg et al., 2019) with high heterogeneity on purpose, scope, theoretical underpinning, processes, data input, and spatial extent (Tittensor et al., 2018). Based on the ecosystem and societal considerations of the EBFM-NIS fishing, we selected a number of indicators that could be used (Table 1). The selection of indicators will depend on the fishery characteristics, such as location, technique, intensity, spatial extent, and species targeted. Some indicators can be assessed using ecosystem models while others using empirical data or input data by experts (e.g. working conditions, fishing effort). Fisheries modelling is often challenged by the lack of adequate fishery and ecological data (Coll et al., 2015; Bevilacqua et al., 2016), uncertainty in assessments (Natugonza et al., 2020), and empirical evidence of impact of other environmental and human stressors (Chagaris et 
al., 2019). To address gaps and ensure success of the analysis, recommendations and best practices can be followed such as utilization of fishers' and stakeholders' ecological knowledge to fill gaps in modelling (Bevilacqua et al., 2016), use and intercomparison of multiple models to limit uncertainty (Tittensor et al., 2018), continued communication and periodic review between stakeholders, modellers, and managers throughout the process to refine and ensure the utility and credibility of the model, and to avoid rejection of outcomes at a later stage (Rees et al., 2013; Townsend et al., 2019).

Table 1. Indicators to monitor the fishery performance.

\begin{tabular}{|ll|}
\hline Group & Indicator \\
\hline Fishery \& Fleet & Catch volume \\
& Revenue \\
& Profit \\
& Catch efficiency \\
& Fishing effort \\
& Exploitation rate \\
& Capital costs \\
& Job creation \\
Working conditions & Job seasonality \\
& Bycatch / Discards \\
Environmental & Damage to habitats \\
& Ghost fishing \\
& Compliance and monitoring \\
\hline
\end{tabular}

Expert elicitation of NIS fishery performance and NIS impacts can be useful in deciding the concerted approach (Plan A or B) of the Mediterranean countries against certain NIS. However, it cannot guide investment strategies, as it does not account for the local characteristics of each area. For that, a sustainability appraisal framework can be used, to consider all five capital assets (natural, physical, human, financial, and social) (DFID, 1999).

Example of local assets that can be taken into consideration include:

Natural capital:

(i) Health of marine habitats (e.g. species composition, richness, and diversity)

(ii) Health of commercial species populations (e.g. abundance, spawning stock biomass)

(iii) Level of protection of marine ecosystems

(iv) Profile and intensity of illegal activities that could affect natural resources

Human capital: 
(i) Level of public education

(ii) Availability of data and systems that flow information which could affect knowledge, skills, and competencies

Social capital:

(i) Communication networks within the communities

(ii) Collaboration, participation, and engagement of the communities

Physical capital:

(i) Infrastructure available for NIS products preservation and processing

(ii) Availability of equipment related to NIS fishing that conforms to sustainability criteria

Financial capital:

(i) Financial capability of citizens to buy NIS products

(ii) Public demand for NIS products that could affect the potential sales (quantity and prices) of NIS products.

The aforementioned processes could be used to guide the development of a comprehensive, explicit, structured risk analysis framework after the engagement of all relevant stakeholders from policy makers to managers and fishers. In all our proposed evaluation frameworks, namely expert elicitation, fishery indicators, and sustainability appraisal, there are limitations which have been highlighted and should be carefully examined prior any decision on the approach to fishery reform. In addition, the complexity in managing species that have both positive and negative impacts can lead to inherent disagreements amongst stakeholders regarding the proposed management strategies. The behaviour of diverse stakeholders and the drivers of these behaviours must be taken into account to achieve success (Alter et al., 2019). The decision processes should be transparent with enhanced stakeholders' engagement to minimize conflicts and limit wickedness. An emerging method of stakeholder engagement is the scenario based planning which enables stakeholders to bridge the gap by choosing the most agreeable solutions based on a limited number of proposed measures (Woodford et al., 2016). Decisions should be subject of rigorous monitoring, constant adaptation to changing conditions and external stimuli, e.g. climate change and overfishing effects, and facilitate reflection and improvement.

\subsection{Fishery reforms}

\subsubsection{Plan A: Sustainable exploitation of NIS}

The exploitation and consumption of edible and conspicuous NIS has been increasingly promoted as a measure to increase pressure on NIS populations and turn these species into a food source and an economic benefit for local communities (Giakoumi et al., 2019a; Kleitou et al., 2019b). Despite this, 
managers have been reluctant to promote and develop strategies to exploit NIS in the Mediterranean Sea influenced by the widespread impression that all NIS have negative impacts.

Recently, the General Fisheries Commission for the Mediterranean (GFCM) listed the creation of adaptation strategies to cope with the potential effects of invasive species on fisheries as target outputs of the mid-term strategy (2017-2020) (FAO, 2017). Amongst the strategies developed, the most notable is the Recommendation GFCM/42/2018/7, following calls from Algeria, Tunisia, and the EU, which establishes a regional research programme to fill scientific and research gaps concerning the crabs Callinectes sapidus Rathbun, 1896 and Portunus segnis (Forskål, 1775). The goal of the recommendation is to maintain the Mediterranean stocks of blue crabs at MSY levels, as well as the socio-economic viability of the blue crab fisheries. An important risk connected to this strategy is the possible reliance of local fishery communities to an invasive NIS or a fishing technique that harms ecosystems and wider ecosystem services. For example, C. sapidus is an invasive predator which according to both anecdotal reports and stable isotopes investigations, can impact benthic communities at multiple trophic levels (Carrozzo et al., 2014; Mancinelli et al., 2016), and damage fishing gears (Culurgioni et al., 2020). A quantitative impact assessment on Ionian and Aegean fisheries in Greece using questionnaire surveys indicated considerable negative effects on fishing activities in areas where C. sapidus reached high abundances (Katselis, unpublished data in Mancinelli et al., 2017). A thorough assessment of NIS impacts on ecosystem services to the wider Mediterranean region, including impacts on other fisheries, is needed before deciding to support the sustainable exploitation of 'questionable species' (Figure 2). Fisheries for NIS should be regulated by the GFCM and contracting parties would need to perform stock assessments and set catch limits. Current restrictions on fishing techniques should remain for fisheries that cause habitat destruction, have high bycatch rates of native species, or generally cause injuries and/or mortalities to the local biota. The example of blue crabs sets a good starting point for the management of NIS in the region, but a structured, adaptive and iterative management strategy that focuses on more NIS should be facilitated.

\subsubsection{Plan B: Unsustainable exploitation of NIS}

After detailed cost-benefit analysis, many NIS will likely fall into the 'unsustainable' category and fisheries for those NIS should be managed to reduce their impacts and populations. We suggest reforms to the current legal framework and the introduction of local permits for NIS fishing.

\subsubsection{Reforms in the current fishery legislation}

Management of NIS fisheries in Mediterranean countries is limited to national and regional legislation, with daily bag restrictions, spatio-temporal regulations of fishing activities, fishing gear deployment limits, and minimum size restrictions for certain species (e.g. EU/1967/2006, EU/1380/2013, EU/2019/982). These regulations were not designed with the invasive fisheries in mind 
and therefore require scrutiny and reassessment for selected invasive NIS. For example, the lionfish Pterois miles (Bennett, 1828) has recently become established in the Mediterranean and is likely to impact regional ecosystems (Kletou et al., 2016; Poursanidis et al., 2020; Savva et al., 2020). Regulations such as daily bag restrictions can be adapted in order to allow fishers, using spearguns, to legally remove as many lionfish individuals as possible.

\subsubsection{Turn recreational fishery to NIS targeted fishery}

Recreational fishing pressure on certain species can exceed commercial pressure, especially if the exploitation is selective and intensive (Lloret et al., 2018; Nillos Kleiven et al., 2019). The total impact of the recreational fishery on fish stocks, and mostly on large and long-lived species with high reproductive potential, is very high and unsustainable for the fish stocks of many countries (Lloret et al., 2008; Lindfield et al., 2014). Recreational fisheries can also impact the trophic structure of coastal ecosystems (Lewin et al., 2006; Lloret et al., 2008). For instance, recreational fishing has had a significant impact on sea bass stocks, Dicentrarchus labrax (Linnaeus, 1758), in France (Rocklin et al., 2014)' (ICES, 2018), and triggered the EU to call for an 80\% reduction in landings (Armstrong, 2014). In other cases, target species for recreational fisheries can threaten native species which are included in the IUCN Red List, e.g. Pagrus pagrus (Linnaeus, 1758) and species of the genus Epinephelus Bloch, 1793 (Unal et al., 2010; Sbragaglia et al., 2019). Driven by motivations other than making profits such as personal enjoyment, sense of freedom, and catch consumption, recreational fishers might continue targeting a NIS even when overfished (Kleiven et al., 2019).

With the introduction of a NIS-specific fishing licence, recreational fishing could be transformed from a threat to biodiversity to an advantage. Local competent authorities (e.g. a governmental body or an MPA authority in collaboration with a not-for-profit national recreational fishery association) could i) guide and control NIS fishing intensity and area; ii) provide licenses; and iii); enable transparency and control of the market chain. Profits of such a scheme could sustain the licensing system, support monitoring, and be invested in the education and capacity of its members. Similar schemes already exist for terrestrial hunting in Mediterranean countries and could be used as examples (e.g. in Greece, the Hellenic Hunters Confederation with surveillance from the Government is responsible for the licensing system of hunters. Part of the revenues from the system is reinvested in supporting a third public monitoring scheme, research and awareness events).

The choice of licensed target species would depend on local conditions and perceptions. To avoid potential conflicts with commercial fishers, the target species may be NIS with low-moderate economic value, but with high socioeconomic and/or negative impacts on commercial fish stocks, or species that are difficult to target by commercial fisheries (e.g. species living in very shallow waters). Commercial and recreational fisheries often target the same resources; thus, directing the recreational fishery to other species will also likely promote acceptance and collaboration between them. This change can be 
conveyed by social norms, perceptions and beliefs, and information through a behavioural management approach (Battista et al., 2018; Mackay et al., 2018), which may constitute a low-cost and highly effective tool for recreational fisheries management (Mackay et al., 2018).

Non-Indigenous Species (NIS) license conditions could include operator training in the marine environment, NIS impacts, as well as identification, safe harvesting, and handling of target species. Licence holders could benefit from indirect measures that promote NIS targeting, such as preclusion of selected areas/time periods for unlicensed recreational and commercial fishers. Finally, financial incentives (or similar incentives such as a free recreational fishery licence) can be given to NIS fishers who remove and deliver selected NIS, with authorities subsequently responsible to sell the specimens in the market, as a compensation for their expenses.

Such a scheme could: i) tackle invasive species using fishing gears with high species selectivity; ii) improve regulation of recreational fisheries while monitoring recreational fishing intensity by type and area, iii) enhance monitoring of NIS distribution, abundance, and ecology; iv) improve public awareness on NIS and other environmental issues, facilitating participation in marine conservation, collaboration, and public stewardship; v) decrease illegal, unreported, and unregulated (IUU) fishing activities by recreational fishers; and vi) improve the market potential of low-value species and generate extra motive even to commercial fishers.

\subsection{Investment in capital assets}

Prevention of introductions is widely accepted as the best approach to deal with NIS. This opinion is reflected in the Aichi Target 9 from the Convention for Biological Diversity (CBD) as well as the EU Regulation (1143/2014) which recommends a hierarchy of prevention, then rapid eradication, and lastly ongoing management. A fishery based on NIS is a type of 'biodiversity offsetting' that aims to reduce, halt, or reverse the losses of biodiversity (Niner et al., 2017) from the introduction and spread of NIS caused by human activities. Within the context of protecting natural fishery resources, conservation measures such as rehabilitation of marine ecosystems through natural capital assets protection and/or restoration should be a priority.

Investments in fishery assets related to the manufactured/natural assets for improved NIS fishery efficiency, market for higher NIS products value, and human and social capital are also essential towards the sustainable NIS exploitation. To this end, we believe that EBFMS-NIS governance can be facilitated with investments in both the (natural) capital assets of the environment and of the fishery itself. 


\subsubsection{Environmental investment (natural capital assets)}

The presence of a healthy functioning ecosystem has the potential to control the distribution and abundances of introduced species and dampen their induced trophic cascade (DeRivera et al., 2005; Carlsson et al., 2011; Papacostas and Freestone, 2019). Overfishing is ubiquitous in the Mediterranean Sea, with benthic ecosystems strongly depleted in finfish, especially in invertivores and top predators (Boudouresque et al., 2017). Simulations have shown that fishing disturbance has been helping some NIS gain an advantage over native species through modifying predator-prey relationships (Saygu et al., 2020).

We discuss three environmental investment measures that could be used to enhance ecosystems capacity, resilience, and resistance against NIS, namely:

- Enhancement of MPAs using Ecosystem Based Management (EBM) approach

- Harvesting of NIS within MPAs

- Protection of overfished predators and key species

Each location has its unique social and ecological context that influences the success of fishery conservation measures against NIS; thus, measures can be site-specific and locally implemented.

\subsubsection{Enhance MPAs using an EBM approach}

When properly managed, Marine Protected Areas (MPAs) are promoted as an essential tool for reversing the degradation of marine life, able to restore or maintain the ecosystem structure, function, connectivity, and integrity, protect important keystone species and habitats, restore the complexity of ecosystems, and improve ecosystem resilience to pressures such as NIS and climate change (Pieraccini et al., 2017; Sala and Giakoumi, 2017; Laffoley et al., 2019). Thus, enhancement of MPAs in all Mediterranean regions can be promoted in an EBM context where interaction among ecosystem components and activities is recognised (Katsanevakis et al., 2011; Corrales et al., 2018).

It is beneficial if MPAs cover a broad range of environmental conditions and niches to safeguard the functional processes that lead to adaptations due to climate change and other pressures. MPAs that cover habitat mosaics will enable wider ecosystem performance and recovery (Solandt et al., 2020). No-take marine reserves (no fishing allowed) are considered as the most effective type of MPA able to significantly restore the biomass and structure of fish assemblages, and restore ecosystems to a more complex and resilient state (Sala and Giakoumi, 2017). In the eastern Mediterranean, however, higher biomass of NIS was recorded in no-take zones compared to adjacent unprotected areas and a lack of fishery pressure appeared as the most influential factor benefiting NIS populations within the MPA (Giakoumi et al., 2019b). The high pressure of NIS in these areas can affect and deteriorate the potential benefits of a reduction in fishing effort and targeted harvesting of NIS has been suggested (see next Chapter) (Corrales et al., 2018; Giakoumi et al., 2019b). 


\subsubsection{Targeted NIS removals within MPAs and at early stages of invasions}

It has been shown that protected areas can offer refuge for invasive NIS to spread under climate change (Gallardo et al., 2017). Under the propagule pressure of NIS, MPAs such as those located in the Levantine Basin might not perform as biodiversity conservation areas but as reserves and "seed banks" for NIS, inducing "spillover effect" to adjacent areas (Galil, 2017b). Although NIS are a prevalent issue for MPAs and are the subject of some monitoring, management, and research, preventative measures for NIS are largely absent (Iacarella et al., 2019). Targeted species removals within MPAs have been suggested as a measure to effectively control NIS populations, even for species with high dispersal capacity (Giakoumi et al., 2019a; Giakoumi et al., 2019b). To this end, we suggest the introduction of special licenses for NIS targeted fishing into MPAs, directed both to professional and recreational fishers, with the use of specific techniques (e.g. spearfishing, line fishing with circle hooks, manual removal) depending on the targeted NIS. This could be done under the supervision of the MPA authority and in collaboration and coordination with local (e.g. port) authorities, and given that techniques used do not injure native species.

We draw from the experience of the RELIONMED LIFE project (www.relionmed.eu), which targets lionfish (Pterois miles) and successfully applies a similar scheme in the eastern Mediterranean (Cyprus). Similar schemes could be replicated in other areas of the region. Specifically, a group of $>100$ volunteer scuba divers (Removal Action Team) were motivated, trained, and equipped with the aim to remove the invasive and venomous lionfish $P$. miles from MPAs in Cyprus, and removal events, as well as competitions with awards, have been organised. Similar to all Mediterranean countries (Gaudin and De Young, 2007), harvesting of marine organisms with scuba gear is prohibited and a specific license has been provided which sets specific rules such as the attendance at educational seminars and training with specialized fishing equipment (e.g. Hawaiian slingshots), and the prerequisite that the participant has a 'white criminal record' (no records of criminal offenses) and is environmentally aware. Harvesting by scuba divers is supervised by scientists and controlled by a competent authority. Participants are informed about location, date, and time of upcoming removal events, depending on the capacity (of coastal police or organisers) to patrol and enforce. Participants must be highly (dive) qualified, sign a waiver for accidents and provide a medical fitness declaration. Participants are provided with specialized equipment, and can be fined and memberships terminated if illegal activities are conducted (e.g. the fishing of other species). Preliminary results have shown that removals can limit lionfish populations if applied in a consistent frequency and/or intensity (RELIONMED project unpubl. data). Similar results were found in another previous LIFE project (LIFE RES MARIS) (www.resmaris.eu) which used dark cloths underwater to kill species of the genus Caulerpa Lamouroux, 1809. Results were successful only for a short duration (Bacchetta et al., 2018). Modelling studies can be useful in determining the threshold population levels at which invasive NIS cause damage to the ecosystem (e.g. 
Green et al., 2014) and/or the removal effort required to deplete NIS populations (e.g. Usseglio et al., 2017).

Removal events of NIS within MPAs may not only provide direct benefits to the marine environment but can also provide recreational benefits from the participation of recreational fishers in NIS harvesting. The engagement of sea users in NIS removals may also enhance their knowledge and awareness about invasive NIS and encourages responsible behaviour, increasing environmental stewardship, and participation in conservational efforts, improving public acceptance and compliance with management decisions. On another level, compulsory reporting of catches in the removal events could also help authorities and research centres to understand NIS distribution, abundance, and spread patterns.

In a similar manner, removal teams could prevent NIS from establishing after early detection. Early detection and response has been recommended as a more cost-effective control measure than postestablishment management, and is included in the priorities of management plans and programs (Finnoff et al., 2007; Schulz and Della Vedova, 2014). To this end, established removal teams, coordinated by competent authorities, could support early detection and removal of organisms.

\subsubsection{Protect and enhance overfished predators and key species}

The dramatic decline of high trophic level predators has impacted entire food webs, leading to regime shifts and degraded ecosystem states (Estes et al., 2011). Overfishing of top predators diminishes the resistance of Mediterranean ecosystems to NIS (Kimbro et al., 2013). Some predators can feed on and potentially control NIS without requiring time to become accustomed to their new prey (Giakoumi et al., 2019c). Therefore, it is important to strengthen high-level predators protection and conservation, especially for species that can have a major role in controlling introduced NIS (Mumby et al., 2011; Kleitou et al., 2018). Examples of such protection measures are that of France, which prohibited the commercial, spearfishing, and recreational hook-and-line fishing of groupers, Epinephelus spp. and Mycteroperca rubra (Bloch, 1793) until at least 2023 (Arrêté Arrêté n 2013357-0001 / n ²0133570004), or of Israel, where commercial fishing of elasmobranchs is prohibited (Ariel and Barash, 2015).

\subsubsection{Non-Indigenous Species fishery investment strategies}

Access to capital assets (natural, physical, human, financial, and social capital) can determine the vulnerability or strength of communities engaged in NIS fisheries (Allison and Ellis, 2001); thus influencing the livelihood outcomes and sustainability of proposed management mechanisms. Strategies that leverage capital assets can establish the infrastructure and tools that will support fisher and wider community engagement in the EBFM-NIS. Decisions for investments should consider the local context, conditions, and trends that exist within communities by using an integrated ecological 
and socioeconomic framework. A range of topics for NIS fishery investment are proposed, from market to public awareness and fishery technology, some of which are interlinked (Figure 4).

Investment in NIS fishery assets

\begin{tabular}{|c|c|c|c|}
\hline Community capacity & $\begin{array}{c}\text { Compliance with } \\
\text { legislation }\end{array}$ & $\begin{array}{l}\text { Market of } \\
\text { NIS products }\end{array}$ & $\begin{array}{l}\text { Fishing technologies } \\
\text { and practices }\end{array}$ \\
\hline Awareness & Voluntary compliance & Market demand & Harvesting protocols \\
\hline Knowledge and skills & Legal norms & Valorisation & Innovative technologies \\
\hline $\begin{array}{l}\text { Flow of information } \\
\text { Collaboration }\end{array}$ & & Novel products & Tourism-related fishing \\
\hline
\end{tabular}

Figure 4. Investment strategies proposed that could improve the socioeconomic and environmental sustainability of the NIS fishery. Red arrows indicate that community capacity is impacting the rest of the topics but not the opposite. Strategies can be linked with more than one capital asset, e.g. fishing technologies and practices proposed are interlinked with physical capital, human capital, and social capital.

\subsubsection{Community capacity}

Our EBFM-NIS suggestion provides the opportunity for citizens to be involved in conservationrelated activities and indirectly influence management and policy by improving stewardship, increasing awareness, and strengthening social license and community capacity to address environmental problems. Raising public awareness and developing skills and knowledge are integral components of an effective EBFM-NIS. Citizens/sea-users have been playing a critical role in monitoring NIS in the Mediterranean basin (Giovos et al., 2019; Kleitou et al., 2019a; Kleitou et al., 2020), but have been largely excluded from mitigation efforts. Engagement of public and stakeholders through educational activities and campaigns can secure their acceptance and participation in management interventions such as the participation in NIS fishing and harvesting within MPAs (Kleitou et al., 2019b), in line with the EU Directive (2003/35/EC). Fishers' engagement and representation in management decisions has also been recognised as few of the major attributes fostering Mediterranean MPAs success in achieving healthier ecosystems and social acceptance (Di Franco et al., 2016).

Public awareness and education are top priorities for NIS management in the Mediterranean (Giakoumi et al., 2019a). Citizens can be motivated to consume NIS rather than native species, harvest NIS, and participate in mitigation activities. As several Mediterranean NIS are venomous or poisonous (Galil, 2018), public campaigns and training of sea users are important to avoid accidents related to touching, handling or consumption of these species. In the EU RELIONMED-LIFE project, all fishers and divers participating in lionfish removals are trained in safe handling and equipped with specialized equipment such as lionfish boxes and puncture-resistant gloves.

Finally, information flow can be improved through systems that facilitate open sharing of marine research outputs, best practices, and knowledge related to NIS and their fishery, providing equitable 
access to ocean knowledge. Similar initiatives have been running in the EU FARNET network, which brings together local communities such as managing authorities, citizens, and experts, and aims inter alia to improve the knowledge and capacity, identify and disseminate successful responses to key challenges, ensure flow of information among stakeholders and support cooperation. Recognizing that marine NIS are a regional inter-connected issue, transboundary collaboration between Mediterranean countries is imperative.

\subsubsection{Compliance with legislation}

A behavioural management approach can be promoted to increase awareness and ensure voluntary compliance with legislation (Battista et al., 2018; Mackay et al., 2018). Indeed, our EBFMNIS proposals embed high risks of Illegal, Unreported and Unregulated (IUU) fishing, particularly within MPAs. Thus, an increase of fishing activities is likely to increase the need for patrols, especially for the recreational-related fishing activities which are already a big proportion of illegal fishing activities, e.g. in a case study analysing Greek fisheries, almost half of the infringements were conducted by recreational fishers (Moutopoulos et al., 2017). The problem gets even more complicated when considering the various duties of the control authorities (e.g. border control and marine safety and security), and this may limit their operational effectiveness especially during summertime when tourist and marine recreational activities are intensive.

Indirect suggestions or reinforcement (i.e. nudges) through a behavioural approach represent a potential inexpensive and highly-effective tool for recreational fisheries management (Mackay et al., 2018). Examples include prohibition of areas for recreational fishers but not for NIS fishers, or even prohibition of recreational fishing on certain days/seasons of the year but not for NIS fishers, and/or an involuntary and cheaper (than normal recreational licenses) license to NIS fishers. An indicative cost for the license can be attributed to subscription to conservation efforts against NIS and accompanied with education material to (re)inform participants about the purpose of their license. Behavioural measures to promote NIS might be easier in areas where NIS are abundant such as in the eastern Mediterranean.

Legal norms that set the conditions to facilitate social capital changes can also be established. These include the obligation of reporting, membership terminations in cases of violations, and prohibitive penalties. Small penalties encourage illegal fishing and enhance a sense of impunity (Andrews-Chouicha and Gray, 2005). In this context, fines should be dissuasive compared with the economic income generated from the black market. Other consequences for the culprits, such as temporal/permanent ban of access to public assistance, subsidies, liability insurances, vessel confiscation, and even jail sentences (Le Gallic and Cox, 2006; Moutopoulos et al., 2016; Soyer et al., 2018) can be applied to anyone involved in the trade of illegal, unreported, and unregulated products of the present activities, such as fishers, dealers, processors, and sellers. 


\subsubsection{Market potential}

Market promotion and exploration of valorisation opportunities (e.g. Hamdi et al., 2018; Jiménez-Muñoz et al., 2019) are imperative to build incentives and ensure the sustainability of NIS fisheries. Similar efforts have already been initiated in the Mediterranean. For example, an important action of the RELIONMED-LIFE project is the exploration of lionfish known uses to make removals sustainable. The project specifically explores the market potential of lionfish as a delicacy at the Cyprus restaurant business industry, and its fins in the jewellery and artwork industry. A similar approach is followed by another project ('Pick the Alien', www.isea.com.gr/pick-the-alien-2) in the Cyclades islands in Greece, where the consumption of NIS is promoted through the creation of a recipe e-book, public events with renowned chefs cooking NIS fishes and discussions with key stakeholders for the development of pilot market chains in the islands.

Through such marketing, local communities may be triggered to protect NIS (Nuñez et al., 2012). To avoid this, control, education, and awareness building would be needed. In addition, people can become aware of which NIS products are edible and develop a preference over native overfished species. Countries with utilization and high demand for a specific NIS could share experiences and recipes with other (e.g. Siganus rabbitfish are highly valued fish market products in countries such as Cyprus, Israel, and Lebanon, but at the same time are discarded in most parts of Greece).

Research can play a critical role in valorisation and marketing of inedible or novel NIS products for economic profit. For instance, the GoJelly project (gojelly.eu), funded by the EU Horizon 2020, aims to develop protocols for handling, preserving, and processing jellyfish to make commercial products (animal feed, fertilizers, cosmetic and nutraceutical, and human food), and promising results can be used for the exploitation of the non-indigenous jellyfishes in the Mediterranean. Caulerpa cylindracea Sonder, 1845 holds potential to become one of the alternatives for the production of bioplastics, and for the development of functional foods for human nutrition, aquaculture, and/or drugs for treating chronic diseases (e.g. diabetes, obesity, atherosclerosis) (Stabili et al., 2016; Vitale et al., 2018). The seagrass Halophila stipulacea (Forsskål) Ascherson, 1867 has bioactive metabolites with promising activities against obesity and biofouling (Bel Mabrouk et al., 2020). The exoskeleton of the spider crab Libinia dubia H. Milne Edwards, 1834 can be used to extract bioactive molecules (RjibaBahri et al., 2019), carotenoid compounds from the blue crab Portunus segnis have potential in food or pharmaceutical industries (Hamdi et al., 2020), and the tetrodotoxin, a neurotoxin present in many invasive and abundant pufferfish such as Lagocephalus sceleratus (Gmelin, 1789) and Torquigener flavimaculosus (Hardy \& Randall, 1983) (Katikou et al., 2009; Kosker et al., 2018), could be used as analgesic, e.g. to safely relieve severe, treatment-resistant, cancer pain (Hagen et al., 2008).

\subsubsection{Fishing technologies and practices}

i) Fishery equipment for NIS 
Developing fishery techniques that reduce bycatch, eliminate discards, and minimize ecological impacts are primary aims of ecosystem-based fishery management (Chopin and Suuronen, 2009). Within the non-indigenous species context, fishery techniques need to be optimized to improve NIS catches, reduce by-catch, and allow fisheries for NIS in areas where this was previously not possible. For example, the GoJelly project developed protocols to allow jellyfish biomass collection during jellyfish blooms. Many of the jellyfish blooms consist of NIS and, particularly in the eastern Mediterranean Sea, they characterize recurrent jellyfish outbreaks (Ghermandi et al., 2015; Gravili, 2019).

Climate change and a recent enlargement of the Suez Canal is allowing thermophilic species to establish viable populations and spread into vulnerable habitats (Galil et al., 2019). A lack of fishing pressure on NIS populations can undermine marine conservation management efforts (Andradi-Brown et al., 2017). In the Western Atlantic, innovative harvest technologies have been proposed to remove lionfish from deeper waters using spiny lobster traps (Pitt and Trott, 2013; Harris et al., 2020) or weaponized remotely operated vehicles (Gittings, 2019). Development of technologies for selective harvesting of NIS can provide an alternative source of income and lower the impacts of highly invasive NIS.

\section{ii) Tourism-related fishing}

Fisheries-related tourism is rapidly developing in many Mediterranean regions, , creating new sources of employment and income, and linking local fishing traditions with education and recreational activities (Nicolosi et al., 2016; Kyvelou and Ierapetritis, 2020). Fishery-related tourism covers a wide array of activities such as excursions in professional fishing vessels (known as 'pescatourism'), recreational fishing from a boat (e.g. charter boat) or the shore, learning about fishing, and exploring the marine environment and its biodiversity.

Recently, the EU adopted a resolution on the role of fisheries-related tourism in the diversification of fisheries (2016/2035(INI)), following a procedure which acknowledged the yet untapped potential of fishery tourism and the importance of its promotion. Benefits include; diversification of fisheries and tourism, greater awareness of fish species and how to cook them, and conservation of fish stocks and marine ecosystems, particularly through reduced catches and physical and mental well-being of fishermen and their families through reduced working hours at sea and higher involvement of women (Report A8-0221/2017).

In the fishery-related tourism activities sector, the primary source of income usually derives from the tourists and not from the catches; thus, tourist excursions for NIS fishing would ideally be used to catch low- or no-value species such as poisonous pufferfish (Tetraodontidae). Such activities are already taking place in Cyprus and Greece where charters provide tourists the experience of catching pufferfish using hand and pole-line-fishing techniques. Fishery-related tourism activities that focus on NIS could 
be further promoted with incentives by the managers such as sharing of protocols, best-practices, or even financial support. An integrated approach at each location could be performed, making sure that tourism development does not by-pass and affect the interests of the fishery communities, ensure support of the relevant stakeholders, and identify opportunities for maximum sustainable impact.

\section{Conclusions}

In the eastern Mediterranean, non-indigenous species have become an integral part of fishers' livelihoods. Ecosystem Based Fisheries Management of NIS (EBFM-NIS) would help limit the socioeconomic and ecological impacts of established NIS populations. This approach may have many benefits such as protecting natural capital, creating new markets, promoting collaboration, and reducing management costs. It could improve both the viability of fisheries as well as securing improvements in ecosystem function. Thus, the proposed EBFM-NIS strategy can help to achieve several of the interconnected goals of the 2030 Agenda for Sustainable Development, particularly Sustainable Development Goal 14, that aims to conserve and use oceans in a sustainable way, achieve sustainable development of fisheries, and maintain natural marine resources (UN, 2019). In addition, it can help Mediterranean countries to comply with policies, regulations, and conventions related to the NIS and/or the protection of marine resources, such as the goals for the 'Descriptor 2' of the European Marine Strategy Framework Directive: 'Non-Indigenous Species introduced by human activities are at levels that do not adversely alter the ecosystems' (2008/56/EC).

\section{Acknowledgements}

We are grateful to Adi Barash and Matt Lapinski for sharing information about the protection of predators in Israel and France, respectively. This research was supported by the LIFE financial instrument of the European Union in the framework of the project RELIONMED - preventing a lionfish invasion in the Mediterranean through early response and targeted removal (LIFE16 NAT/CY/000832).

\section{References}

Allen, C.R., Garmestani, A.S., 2015. Adaptive management, Adaptive management of socialecological systems. Springer, pp. 1-10.

Allison, E.H., Ellis, F., 2001. The livelihoods approach and management of small-scale fisheries. Mar. Policy 25, 377-388. doi:10.1016/S0308-597X(01)00023-9.

Alter, T., Martin, P., Hine, D., Howard, T., 2019. Community-based Control of Invasive Species. Csiro Publishing.

Andradi-Brown, D.A., Vermeij, M.J., Slattery, M., Lesser, M., Bejarano, I., Appeldoorn, R., Goodbody-Gringley, G., Chequer, A.D., Pitt, J.M., Eddy, C., 2017. Large-scale invasion of western Atlantic mesophotic reefs by lionfish potentially undermines culling-based management. Biol. Invasions 19, 939-954. doi:10.1007/s10530-016-1358-0. 
Andrews-Chouicha, E., Gray, K., 2005. Why fish piracy persists: the economics of illegal, unreported, and unregulated fishing. OECD Publishing, Paris.

Apostolaki, E.T., Vizzini, S., Santinelli, V., Kaberi, H., Andolina, C., Papathanassiou, E., 2019.

Exotic Halophila stipulacea is an introduced carbon sink for the Eastern Mediterranean Sea. Sci. Rep.

9, 1-13. doi:10.1038/s41598-019-45046-w.

Ariel, A., Barash, A., 2015. Action Plan for Protection of Sharks and Rays in the Israeli

Mediterranean. EcoOcean Association.

Armstrong, M., 2014. Assessment of recreational fisheries for seabass, Request for Services - Sea bass. Commitment No.686192. Paper for STECF.

Azzurro, E., Sbragaglia, V., Cerri, J., Bariche, M., Bolognini, L., Souissi, J.B., Busoni, G., Coco, S., Chryssanthi, A., Garrabou, J., 2019. The shifting distribution of Mediterranean fishes: a spatiotemporal assessment based on Local Ecological Knowledge. Glob Change Biol 25. doi:10.1111/gcb.14670.

Bacchetta, G., Bordigoni, A., Cinti, M.F., Frau, F., Lentini, L., Liggi, M.G., Meloni, F., Orrù, M., Podda, L., Sanna, A., 2018. Handbook of good practices and guidelines for the correct enjoyment and management of natural habitats in the beach system.

Bacher, S., Blackburn, T.M., Essl, F., Genovesi, P., Heikkilä, J., Jeschke, J.M., Jones, G., Keller, R., Kenis, M., Kueffer, C., 2018. Socio-economic impact classification of alien taxa (SEICAT). Methods Ecol. Evol. 9, 159-168. doi:10.1111/2041-210X.12844.

Battista, W., Romero-Canyas, R., Smith, S.L., Fraire, J., Effron, M., Larson-Konar, D., Fujita, R., 2018. Behavior change interventions to reduce illegal fishing. Front. Mar. Sci. 5, 403.

doi:10.3389/fmars.2018.00403.

Bel Mabrouk, S., Reis, M., Sousa, M.L., Ribeiro, T., Almeida, J.R., Pereira, S., Antunes, J., Rosa, F., Vasconcelos, V., Achour, L., 2020. The Marine Seagrass Halophila stipulacea as a Source of

Bioactive Metabolites against Obesity and Biofouling. Mar. Drugs 18, 88. doi:10.3390/md18020088. Bevilacqua, A.H.V., Carvalho, A.R., Angelini, R., Christensen, V., 2016. More than anecdotes:

fishers' ecological knowledge can fill gaps for ecosystem modeling. PLoS One 11, e 0155655.

Bonanno, G., 2016. Alien species: to remove or not to remove? That is the question. Environ. Sci.

Policy 59, 67-73. doi:10.1016/j.envsci.2016.02.011.

Boudouresque, C.-F., 2004. Marine biodiversity in the Mediterranean: status of species, populations and communities. Trav. Sci. Parc Natl. Port-Cros 20, 97-146.

Boudouresque, C.-F., Blanfuné, A., Fernandez, C., Lejeusne, C., Pérez, T., Ruitton, S., Thibault, D., Thibaut, T., Verlaque, M., 2017. Marine Biodiversity-Warming vs. Biological Invasions and overfishing in the Mediterranean Sea: Take care, 'One Train can hide another'. MOJ Eco Environ Sci 2, 1-13. doi:10.15406/mojes.2017.02.00031.

Carboneras, C., Genovesi, P., Vilà, M., Blackburn, T.M., Carrete, M., Clavero, M., D'hondt, B., Orueta, J.F., Gallardo, B., Geraldes, P., 2018. A prioritised list of invasive alien species to assist the effective implementation of EU legislation. J. Appl. Ecol. 55, 539-547. doi:10.1111/1365-

2664.12997.

Carlsson, N.O., Bustamante, H., Strayer, D.L., Pace, M.L., 2011. Biotic resistance on the increase: native predators structure invasive zebra mussel populations. Freshw. Biol. 56, 1630-1637. doi:10.1111/j.1365-2427.2011.02602.x.

Carrozzo, L., Potenza, L., Carlino, P., Costantini, M.L., Rossi, L., Mancinelli, G., 2014. Seasonal abundance and trophic position of the Atlantic blue crab Callinectes sapidus Rathbun 1896 in a Mediterranean coastal habitat. Rendiconti Lincei 25, 201-208. doi:10.1007/s12210-014-0297-x. Cassey, P., García-Díaz, P., Lockwood, J.L., Blackburn, T.M., 2018. Invasion biology: searching for predictions and prevention, and avoiding lost causes. Invasion Biol Hypotheses Evid 9.

Chaffin, B.C., Garmestani, A.S., Angeler, D.G., Herrmann, D.L., Stow, C.A., Nyström, M.,

Sendzimir, J., Hopton, M.E., Kolasa, J., Allen, C.R., 2016. Biological invasions, ecological resilience and adaptive governance. J. Environ. Manage. 183, 399-407.

doi:https://doi.org/10.1016/j.jenvman.2016.04.040.

Chagaris, D., Sagarese, S., Farmer, N., Mahmoudi, B., de Mutsert, K., VanderKooy, S., Patterson III, W.F., Kilgour, M., Schueller, A., Ahrens, R., 2019. Management challenges are opportunities for fisheries ecosystem models in the Gulf of Mexico. Mar. Policy 101, 1-7. 
Cheung, W.W., Watson, R., Pauly, D., 2013. Signature of ocean warming in global fisheries catch. Nature 497, 365. doi:10.1038/nature12156.

Chopin, F., Suuronen, P., 2009. The development of international guidelines on bycatch management and reduction of discards. ICES CM 1000, 01.

Claudet, J., Fraschetti, S., 2010. Human-driven impacts on marine habitats: a regional meta-analysis in the Mediterranean Sea. Biol. Conserv. 143, 2195-2206. doi:10.1016/j.biocon.2010.06.004. Coll, M., Akoglu, E., Arreguin-Sanchez, F., Fulton, E., Gascuel, D., Heymans, J., Libralato, S., Mackinson, S., Palomera, I., Piroddi, C., 2015. Modelling dynamic ecosystems: venturing beyond boundaries with the Ecopath approach. Rev. Fish Biol. Fish. 25, 413-424.

Coll, M., Piroddi, C., Steenbeek, J., Kaschner, K., Lasram, F.B.R., Aguzzi, J., Ballesteros, E., Bianchi, C.N., Corbera, J., Dailianis, T., 2010. The biodiversity of the Mediterranean Sea: estimates, patterns, and threats. PLoS One 5, e11842. doi:10.1371/journal.pone.0011842.

Colson, A.R., Cooke, R.M., 2018. Expert elicitation: using the classical model to validate experts' judgments. Review of Environmental Economics and Policy 12, 113-132.

Corrales, X., Coll, M., Ofir, E., Heymans, J.J., Steenbeek, J., Goren, M., Edelist, D., Gal, G., 2018. Future scenarios of marine resources and ecosystem conditions in the Eastern Mediterranean under the impacts of fishing, alien species and sea warming. Sci. Rep. 8, 14284.

doi:https://doi.org/10.1038/s41598-018-32666-X.

Corsini-Foka, M., Kondylatos, G., 2015. Native and alien ichthyofauna in coastal fishery of Rhodes (eastern Mediterranean)(2002-2010), Frontiers in Marine Science Conference Abstract: XV European Congress of Ichthyology.

Culurgioni, J., Diciotti, R., Satta, C., Camedda, A., de Lucia, G., Pulina, S., Lugliè, A., Brundu, R., Fois, N., 2020. Distribution of the alien species Callinectes sapidus (Rathbun, 1896) in Sardinian waters (western Mediterranean). Bioinvasions Rec 9, 65-73. doi:10.3391/bir.2020.9.1.09

DeRivera, C.E., Ruiz, G.M., Hines, A.H., Jivoff, P., 2005. Biotic resistance to invasion: native predator limits abundance and distribution of an introduced crab. Ecology 86, 3364-3376.

doi:10.1890/05-0479.

DFID, U., 1999. Sustainable livelihoods guidance sheets. London: DFID 445.

Di Franco, A., Thiriet, P., Di Carlo, G., Dimitriadis, C., Francour, P., Gutiérrez, N.L., De Grissac, A.J., Koutsoubas, D., Milazzo, M., del Mar Otero, M., 2016. Five key attributes can increase marine protected areas performance for small-scale fisheries management. Sci. Rep. 6, 38135. doi:10.1038/srep38135.

Essl, F., Lenzner, B., Bacher, S., Bailey, S., Capinha, C., Daehler, C., Dullinger, S., Genovesi, P., Hui, C., Hulme, P.E., Jeschke, J.M., Katsanevakis, S., Kühn, I., Leung, B., Liebhold, A., Liu, C., MacIsaac, H.J., Meyerson, L.A., Nuñez, M.A., Pauchard, A., Pyšek, P., Rabitsch, W., Richardson, D.M., Roy, H.E., Ruiz, G.M., Russell, J.C., Sanders, N.J., Sax, D.F., Scalera, R., Seebens, H., Springborn, M., Turbelin, A., van Kleunen, M., von Holle, B., Winter, M., Zenni, R.D., Mattsson, B.J., Roura-Pascual, N., 2020. Drivers of future alien species impacts: An expert-based assessment. Glob. Chang. Biol. n/a. doi:10.1111/gcb.15199.

Estes, J.A., Terborgh, J., Brashares, J.S., Power, M.E., Berger, J., Bond, W.J., Carpenter, S.R., Essington, T.E., Holt, R.D., Jackson, J.B., 2011. Trophic downgrading of planet Earth. Science 333, 301-306. doi:10.1126/science.1205106.

FAO, 2017. Mid-term strategy (2017-2020) towards the sustainability of Mediterranean and Black Sea fisheries. Food and Agriculture Organization of the United Nations, Rome, Italy.

Finnoff, D., Shogren, J.F., Leung, B., Lodge, D., 2007. Take a risk: preferring prevention over control of biological invaders. Ecol. Econ. 62, 216-222. doi:doi:10.1016/j.ecolecon.2006.03.025.

Galanidi, M., Zenetos, A., Bacher, S., 2018. Assessing the socio-economic impacts of priority marine invasive fishes in the Mediterranean with the newly proposed SEICAT methodology. Mediterr. Mar. Sci. 19, 107-123. doi:10.12681/mms.15940.

Galil, B., 2017b. Eyes wide shut: managing bio-invasions in Mediterranean marine protected areas. Management of marine protected areas: A network perspective. Chichester: John Wiley \& Sons Ltd, 187-206. doi:https://doi.org/10.1002/9781119075806.ch10.

Galil, B., 2018. Poisonous and venomous: marine alien species in the Mediterranean Sea and human health, in: Mazza, G., Tricarico, E. (Eds.), Invasive Species and Human Health. CAB International, United Kingdom, pp. 1-15. 
Galil, B.S., Danovaro, R., Rothman, S., Gevili, R., Goren, M., 2019. Invasive biota in the deep-sea Mediterranean: an emerging issue in marine conservation and management. Biol. Invasions 21, 281288. doi:10.1007/s10530-018-1826-9.

Galil, B.S., Marchini, A., Occhipinti-Ambrogi, A., 2018a. East is east and West is west? Management of marine bioinvasions in the Mediterranean Sea. Estuar. Coast. Shelf Sci. 201, 7-16.

doi:10.1016/j.ecss.2015.12.021.

Galil, B.S., Marchini, A., Occhipinti-Ambrogi, A., 2018b. Mare Nostrum, Mare Quod Invaditur-The History of Bioinvasions in the Mediterranean Sea, Histories of Bioinvasions in the Mediterranean. Springer, pp. 21-49.

Gallardo, B., Aldridge, D.C., González-Moreno, P., Pergl, J., Pizarro, M., Pyšek, P., Thuiller, W., Yesson, C., Vilà, M., 2017. Protected areas offer refuge from invasive species spreading under climate change. Glob. Chang. Biol. 23, 5331-5343. doi:10.1111/gcb.13798.

Gaudin, C., De Young, C., 2007. Recreational fisheries in the Mediterranean countries: a review of existing legal frameworks. Food \& Agriculture Org.

Gewing, M.-T., Shenkar, N., 2017. Monitoring the magnitude of marine vessel infestation by nonindigenous ascidians in the Mediterranean. Mar. Pollut. Bull. 121, 52-59.

doi:10.1016/j.marpolbul.2017.05.041.

Ghermandi, A., Galil, B., Gowdy, J., Nunes, P.A., 2015. Jellyfish outbreak impacts on recreation in the Mediterranean Sea: welfare estimates from a socioeconomic pilot survey in Israel. Ecosyst Serv 11, 140-147. doi:10.1016/j.ecoser.2014.12.004.

Giakoumi, S., Katsanevakis, S., Albano, P.G., Azzurro, E., Cardoso, A.C., Cebrian, E., Deidun, A., Edelist, D., Francour, P., Jimenez, C., 2019a. Management priorities for marine invasive species. Sci. Total Environ. 688, 976-982. doi:https://doi.org/10.1016/j.scitotenv.2019.06.282.

Giakoumi, S., Pey, A., Di Franco, A., Francour, P., Kizilkaya, Z., Arda, Y., Raybaud, V., Guidetti, P., 2019b. Exploring the relationships between marine protected areas and invasive fish in the world's most invaded sea. Ecol. Appl. 29, e01809. doi:https://doi.org/10.1002/eap.1809.

Giakoumi, S., Pey, A., Thiriet, P., Francour, P., Guidetti, P., 2019c. Patterns of predation on native and invasive alien fish in mediterranean protected and unprotected areas. Mar. Environ. Res. 150. doi:10.1016/j.marenvres.2019.104792.

Giangrande, A., Pierri, C., Del Pasqua, M., Gravili, C., Gambi, M.C., Gravina, M.F., 2020. The Mediterranean in check: Biological invasions in a changing sea. Mar. Ecol. 41, e12583. doi:10.1111/maec.12583.

Giovos, I., Kleitou, P., Poursanidis, D., Batjakas, I., Bernardi, G., Crocetta, F., Doumpas, N., Kalogirou, S., Kampouris, T.E., Keramidas, I., 2019. Citizen-science for monitoring marine invasions and stimulating public engagement: a case project from the eastern Mediterranean. Biol. Invasions, 115. doi:10.1007/s10530-019-02083-w.

Gittings, S.R., 2019. Apparatus for harvesting lionfish. Google Patents, United States.

Givan, O., Edelist, D., Sonin, O., Belmaker, J., 2018. Thermal affinity as the dominant factor changing Mediterranean fish abundances. Glob. Chang. Biol. 24, e80-e89. doi:10.1111/gcb.13835.

Gravili, C., 2019. Jelly surge in the Mediterranean Sea: threat or opportunity? Mediterr. Mar. Sci. 21, 11-21. doi:10.12681/mms.17966.

Green, S.J., Dulvy, N.K., Brooks, A.M., Akins, J.L., Cooper, A.B., Miller, S., Côté, I.M., 2014. Linking removal targets to the ecological effects of invaders: a predictive model and field test. Ecol. Appl. 24, 1311-1322. doi:https://doi.org/10.1890/13-0979.1.

Hagen, N.A., du Souich, P., Lapointe, B., Ong-Lam, M., Dubuc, B., Walde, D., Love, R., Ngoc, A.H., Group, C.T.S., 2008. Tetrodotoxin for moderate to severe cancer pain: a randomized, double blind, parallel design multicenter study. J. Pain Symptom Manage. 35, 420-429.

doi:10.1016/j.jpainsymman.2007.05.011.

Hamdi, M., Hajji, S., Affes, S., Taktak, W., Maâlej, H., Nasri, M., Nasri, R., 2018. Development of a controlled bioconversion process for the recovery of chitosan from blue crab (Portunus segnis) exoskeleton. Food Hydrocoll 77, 534-548. doi:10.1016/j.foodhyd.2017.10.031.

Hamdi, M., Nasri, R., Dridi, N., Li, S., Nasri, M., 2020. Development of novel high-selective extraction approach of carotenoproteins from blue crab (Portunus segnis) shells, contribution to the qualitative analysis of bioactive compounds by HR-ESI-MS. Food Chem. 302, 125334.

doi:10.1016/j.foodchem.2019.125334. 
Harris, H.E., Fogg, A.Q., Gittings, S.R., Ahrens, R.N., Allen, M.S., Patterson, W.F., 2020. Testing the efficacy of lionfish traps in the northern Gulf of Mexico. bioRxiv.

Hemming, V., Burgman, M.A., Hanea, A.M., McBride, M.F., Wintle, B.C., 2018. A practical guide to structured expert elicitation using the IDEA protocol. Methods Ecol. Evol. 9, 169-180.

Hornborg, S., van Putten, I., Novaglio, C., Fulton, E.A., Blanchard, J.L., Plagányi, É., Bulman, C., Sainsbury, K., 2019. Ecosystem-based fisheries management requires broader performance indicators for the human dimension. Mar. Policy 108, 103639. doi:10.1016/j.marpol.2019.103639.

Hulme, P.E., 2015. Invasion pathways at a crossroad: policy and research challenges for managing alien species introductions. J. Appl. Ecol. 52, 1418-1424. doi:10.1111/1365-2664.12470.

Iacarella, J.C., Saheed, D., Dunham, A., Ban, N.C., 2019. Non-native species are a global issue for marine protected areas. Front. Ecol. Environ. 245. doi:10.1002/fee.2100.

ICES, 2018. Report from the Working Group on Recreational Fisheries Surveys (WGRFS), 11-15 June 2018. ICES CM 2018/EOSG:19, Faro, Portugal, p. 111.

Jiménez-Muñoz, L., Quintanilla, M., Filomena, A., 2019. Managing the lionfish: influence of high intensity ultrasound and binders on textural and sensory properties of lionfish (Pterois volitans) surimi patties. J. Food Sci. Technol. 56, 2167-2174. doi:10.1007/s13197-019-03698-6.

Kalogirou, S., 2011. Alien fish species in the eastern Mediterranean Sea: Invasion biology in coastal ecosystems, Department of marine ecology. University of Gothenburg, Gothenburg, p. 140.

Kalogirou, S., Azzurro, E., Bariche, M., 2012. The Ongoing Shift of Mediterranean Coastal Fish Assemblages and the Spread of Non-Indigenous Species, in: Lameed, G.A. (Ed.), Biodiversity Enrichment in a Diverse World. InTech, Rijeka, p. Ch. 11.

Katikou, P., Georgantelis, D., Sinouris, N., Petsi, A., Fotaras, T., 2009. First report on toxicity assessment of the Lessepsian migrant pufferfish Lagocephalus sceleratus (Gmelin, 1789) from European waters (Aegean Sea, Greece). Toxicon 54, 50-55. doi:10.1016/j.toxicon.2009.03.012. Katsanevakis, S., Stelzenmüller, V., South, A., Sørensen, T.K., Jones, P.J., Kerr, S., Badalamenti, F., Anagnostou, C., Breen, P., Chust, G., 2011. Ecosystem-based marine spatial management: review of concepts, policies, tools, and critical issues. Ocean Coast. Manage. 54, 807-820.

doi:10.1016/j.ocecoaman.2011.09.002.

Katsanevakis, S., Wallentinus, I., Zenetos, A., Leppäkoski, E., Çinar, M.E., Oztürk, B., Grabowski, M., Golani, D., Cardoso, A.C., 2014. Impacts of invasive alien marine species on ecosystem services and biodiversity: a pan-European review. Aquat Invasions 9, 391-423. doi:10.3391/ai.2014.9.4.01.

Katsanevakis, S., Zenetos, A., Belchior, C., Cardoso, A.C., 2013. Invading European Seas: assessing pathways of introduction of marine aliens. Ocean Coast. Manage. 76, 64-74.

doi:10.1016/j.ocecoaman.2013.02.024.

Killi, N., Tarkan, A.S., Kozic, S., Copp, G.H., Davison, P.I., Vilizzi, L., 2020. Risk screening of the potential invasiveness of non-native jellyfishes in the Mediterranean Sea. Mar. Pollut. Bull. 150, 110728. doi:10.1016/j.marpolbul.2019.110728.

Kimbro, D.L., Cheng, B.S., Grosholz, E.D., 2013. Biotic resistance in marine environments. Ecol. Lett. 16, 821-833. doi:10.1111/ele.12106.

Kleitou, P., Giovos, I., Antoniou, C., Ioannou, G., Bernardi, G., 2020. The third record of blackspotted porcupinefish Diodon hystrix Linnaeus, 1758 in the Mediterranean Sea. J. Appl. Ichthyol. 36, 227-230. doi:10.1111/jai.13999.

Kleitou, P., Giovos, I., Wolf, W., Crocetta, F., 2019a. On the importance of citizen-science: the first record of Goniobranchus obsoletus (Rüppell and Leuckart, 1830) from Cyprus (Mollusca:

Gastropoda: Nudibranchia). Bioinvasions Rec 8, 252-257. doi:https://doi.org/10.3391/bir.2019.8.2.06 Kleitou, P., Kalogirou, S., Marmara, D., Giovos, I., 2018. Coryphaena hippurus: A potential predator of Lagocephalus sceleratus in the Mediterranean Sea. Int. J. Fish. Aquat. Stud. 6, 93-95.

Kleitou, P., Savva, I., Kletou, D., Hall-Spencer, J.M., Antoniou, C., Christodoulides, Y., Chartosia, N., Hadjioannou, L., Dimitriou, A.C., Jimenez, C., Sfenthourakis, S., Rees, S., 2019b. Invasive lionfish in the Mediterranean: Low public awareness yet high stakeholder concerns. Mar. Policy 104, 66-74. doi:https://doi.org/10.1016/j.marpol.2019.02.052.

Kleiven, A.R., Moland, E., Sumaila, U.R., 2019. No fear of bankruptcy: the innate self-subsidizing forces in recreational fishing. ICES J. Mar. Sci., doi:10.1093/icesjms/fsz128.

Kletou, D., Hall-Spencer, J.M., Kleitou, P., 2016. A lionfish (Pterois miles) invasion has begun in the Mediterranean Sea. Mar. Biodivers. Rec. 9, 46. doi:10.1186/s41200-016-0065-y. 
Kolar, C.S., Lodge, D.M., 2001. Progress in invasion biology: predicting invaders. Trends Ecol. Evol. 16, 199-204. doi:10.1016/S0169-5347(01)02101-2.

Kosker, A.R., Özogul, F., Durmus, M., Ucar, Y., Ayas, D., Šimat, V., Özogul, Y., 2018. First report on TTX levels of the yellow spotted pufferfish (Torquigener flavimaculosus) in the Mediterranean

Sea. Toxicon 148, 101-106. doi:10.1016/j.toxicon.2018.04.018.

Kyvelou, S.S.I., Ierapetritis, D.G., 2020. Fisheries Sustainability through Soft Multi-Use Maritime Spatial Planning and Local Development Co-Management: Potentials and Challenges in Greece. Sustainability 12, 2026. doi:10.3390/su12052026.

Lacoue-Labarthe, T., Nunes, P.A., Ziveri, P., Cinar, M., Gazeau, F., Hall-Spencer, J.M., Hilmi, N., Moschella, P., Safa, A., Sauzade, D., 2016. Impacts of ocean acidification in a warming Mediterranean Sea: An overview. Reg. Stud. Mar. Sci. 5, 1-11. doi:10.1016/j.rsma.2015.12.005. Laffoley, D., Baxter, J.M., Day, J.C., Wenzel, L., Bueno, P., Zischka, K., 2019. Marine protected areas, World Seas: an Environmental Evaluation. Elsevier, pp. 549-569.

Last, P.R., White, W.T., Gledhill, D.C., Hobday, A.J., Brown, R., Edgar, G.J., Pecl, G., 2011. Longterm shifts in abundance and distribution of a temperate fish fauna: a response to climate change and fishing practices. Global Ecol. Biogeogr. 20, 58-72. doi:10.1111/j.1466-8238.2010.00575.x.

Le Gallic, B., Cox, A., 2006. An economic analysis of illegal, unreported and unregulated (IUU) fishing: Key drivers and possible solutions. Mar. Policy 30, 689-695.

doi:10.1016/j.marpol.2005.09.008.

Levin, P.S., Essington, T.E., Marshall, K.N., Koehn, L.E., Anderson, L.G., Bundy, A., Carothers, C., Coleman, F., Gerber, L.R., Grabowski, J.H., 2018. Building effective fishery ecosystem plans. Mar. Policy 92, 48-57. doi:10.1016/j.marpol.2018.01.019.

Lewin, W.-C., Arlinghaus, R., Mehner, T., 2006. Documented and potential biological impacts of recreational fishing: insights for management and conservation. Rev. Fish. Sci. 14, 305-367. doi:10.1080/10641260600886455.

Lindfield, S.J., McIlwain, J.L., Harvey, E.S., 2014. Depth refuge and the impacts of SCUBA spearfishing on coral reef fishes. PLoS One 9, e92628. doi:10.1371/journal.pone.0092628.

Liquete, C., Piroddi, C., Macías, D., Druon, J.-N., Zulian, G., 2016. Ecosystem services sustainability in the Mediterranean Sea: assessment of status and trends using multiple modelling approaches. Sci.

Rep. 6, 34162. doi:10.1038/srep34162.

Lloret, J., Cowx, I.G., Cabral, H., Castro, M., Font, T., Gonçalves, J.M., Gordoa, A., Hoefnagel, E., Matić-Skoko, S., Mikkelsen, E., 2018. Small-scale coastal fisheries in European Seas are not what they were: ecological, social and economic changes. Mar. Policy 98, 176-186.

doi:10.1016/j.marpol.2016.11.007.

Lloret, J., Zaragoza, N., Caballero, D., Font, T., Casadevall, M., Riera, V., 2008. Spearfishing pressure on fish communities in rocky coastal habitats in a Mediterranean marine protected area. Fish Res 94, 84-91. doi:10.1016/j.fishres.2008.07.002.

Mackay, M., Jennings, S., van Putten, E., Sibly, H., Yamazaki, S., 2018. When push comes to shove in recreational fishing compliance, think 'nudge'. Mar. Policy 95, 256-266.

doi:10.1016/j.marpol.2018.05.026.

Mancinelli, G., Chainho, P., Cilenti, L., Falco, S., Kapiris, K., Katselis, G., Ribeiro, F., 2017. The Atlantic blue crab Callinectes sapidus in southern European coastal waters: Distribution, impact and prospective invasion management strategies. Mar. Pollut. Bull. 119, 5-11.

doi:10.1016/j.marpolbul.2017.02.050.

Mancinelli, G., Glamuzina, B., Petrić, M., Carrozzo, L., Glamuzina, L., Zotti, M., Raho, D., Vizzini, S., 2016. The trophic position of the Atlantic blue crab Callinectes sapidus Rathbun 1896 in the food web of Parila Lagoon (South Eastern Adriatic, Croatia): a first assessment using stable isotopes. Mediterr. Mar. Sci. 17, 634-643. doi:10.12681/mms.1724.

Marshall, K.N., Levin, P.S., Essington, T.E., Koehn, L.E., Anderson, L.G., Bundy, A., Carothers, C., Coleman, F., Gerber, L.R., Grabowski, J.H., 2018. Ecosystem-based fisheries management for socialecological systems: renewing the focus in the United States with next generation fishery ecosystem plans. Conserv Lett 11, e12367. doi:10.1111/conl.12367.

Martin, T.G., Burgman, M.A., Fidler, F., Kuhnert, P.M., Low-Choy, S., McBride, M., Mengersen, K., 2012. Eliciting expert knowledge in conservation science. Conserv. Biol. 26, 29-38.

doi:10.1111/j.1523-1739.2011.01806.x. 
Martinez-Cillero, R., Willcock, S., Perez-Diaz, A., Joslin, E., Vergeer, P., Peh, K.S.H., 2019. A practical tool for assessing ecosystem services enhancement and degradation associated with invasive alien species. Ecol. Evol. 9, 3918-3936. doi:10.1002/ece3.5020.

Michailidis, N., Corrales, X., Karachle, P.K., Chartosia, N., Katsanevakis, S., Sfenthourakis, S., 2019. Modelling the role of alien species and fisheries in an Eastern Mediterranean insular shelf ecosystem. Ocean Coast. Manage. 175, 152-171.

Moullec, F., Barrier, N., Guilhaumon, F., Marsaleix, P., Somot, S., Shin, Y.-J., 2019. An End-to-End model reveals losers and winners in a warming Mediterranean Sea. Frontiers in Marine Science 6, 345. doi:10.3389/fmars.2019.00345.

Moutopoulos, D., Dimitriou, E., Katselis, G., Koutsikopoulos, C., 2017. Typology of illegal fishing in transitional waters: Fisheries infringement records from Mesolonghi-Etolikon lagoons (Ionian Sea, Greece). Ocean Coast. Manage. 141, 20-28. doi:10.1016/j.ocecoaman.2017.03.007.

Moutopoulos, D.K., Prodromitis, G., Mantzouni, I., Koutsikopoulos, C., 2016. Quantifying the implementation of Common Fisheries Policy: Patterns of fisheries violations and penalties imposed in Greek waters. Mar. Policy 70, 65-76. doi:10.1016/j.marpol.2016.04.036.

Mumby, P.J., Harborne, A.R., Brumbaugh, D.R., 2011. Grouper as a natural biocontrol of invasive lionfish. PLoS One 6, e21510. doi:10.1371/journal.pone.0021510.

Natugonza, V., Ainsworth, C., Sturludóttir, E., Musinguzi, L., Ogutu-Ohwayo, R., Tomasson, T., Nyamweya, C., Stefansson, G., 2020. Ecosystem modelling of data-limited fisheries: How reliable are Ecopath with Ecosim models without historical time series fitting? J. Great Lakes Res.

Nicolosi, A., Sapone, N., Cortese, L., Marcianò, C., 2016. Fisheries-related tourism in southern Tyrrhenian coastline. Procedia Soc Behav Sci 223, 416-421. doi:10.1016/j.sbspro.2016.05.257. Nillos Kleiven, P.J., Espeland, S.H., Olsen, E.M., Abesamis, R.A., Moland, E., Kleiven, A.R., 2019. Fishing pressure impacts the abundance gradient of European lobsters across the borders of a newly established marine protected area. Proc. Royal Soc 286, 20182455. doi:10.1098/rspb.2018.2455. Niner, H.J., Milligan, B., Jones, P.J., Styan, C.A., 2017. A global snapshot of marine biodiversity offsetting policy. Mar. Policy 81, 368-374. doi:10.1016/j.marpol.2017.04.005.

Nuñez, M.A., Kuebbing, S., Dimarco, R.D., Simberloff, D., 2012. Invasive species: to eat or not to eat, that is the question. Conserv Lett 5, 334-341. doi:10.1111/j.1755-263X.2012.00250.x.

Papacostas, K.J., Freestone, A.L., 2019. Stronger predation in a subtropical community dampens an invasive species-induced trophic cascade. Biol. Invasions 21, 203-215. doi:10.1007/s10530-018-18198.

Peyton, J., Martinou, A.F., Pescott, O.L., Demetriou, M., Adriaens, T., Arianoutsou, M., Bazos, I., Bean, C.W., Booy, O., Botham, M., 2019. Horizon scanning for invasive alien species with the potential to threaten biodiversity and human health on a Mediterranean island. Biol. Invasions 21, 2107-2125. doi:10.1007/s10530-019-01961-7.

Pieraccini, M., Coppa, S., De Lucia, G.A., 2017. Beyond marine paper parks? Regulation theory to assess and address environmental non-compliance. Aquat. Conserv.: Mar. Freshwat. Ecosyst. 27, $177-$ 196. doi:10.1002/aqc.2632.

Pikitch, E.K., Santora, C., Babcock, E.A., Bakun, A., Bonfil, R., Conover, D.O., Dayton, P., Doukakis, P., Fluharty, D., Heneman, B., 2004. Ecosystem-based fishery management. 305, 346-347. doi:10.1126/science.1098222.

Pitcher, T., Preikshot, D., 2001. rapfish: a rapid appraisal technique to evaluate the sustainability status of fisheries. Fisheries Center. University of British Columbia 49, 255-270. doi:10.1016/S01657836(00)00205-8.

Pitt, J., Trott, T., 2013. Efforts to develop a lionfish-specific trap for use in Bermuda waters. Proceedings of the 66th Gulf and Fisheries Institute, November, 4-8.

Plagányi, É.E., Punt, A.E., Hillary, R., Morello, E.B., Thébaud, O., Hutton, T., Pillans, R.D., Thorson, J.T., Fulton, E.A., Smith, A.D., 2014. Multispecies fisheries management and conservation: tactical applications using models of intermediate complexity. Fish Fish. 15, 1-22. doi:10.1111/j.14672979.2012.00488.x.

Poursanidis, D., Kalogirou, S., Azzurro, E., Parravicini, V., Bariche, M., zu Dohna, H., 2020. Habitat suitability, niche unfilling and the potential spread of Pterois miles in the Mediterranean Sea. Marine Pollution Bulletin 154, 111054. doi:https://doi.org/10.1016/j.marpolbul.2020.111054. 
Pyšek, P., Hulme, P.E., Nentwig, W., 2009. Glossary of the main technical terms used in the handbook, Handbook of alien species in Europe. Springer, pp. 375-379.

Rees, S.E., Attrill, M.J., Austen, M.C., Mangi, S.C., Rodwell, L.D., 2013. A thematic cost-benefit analysis of a marine protected area. J. Environ. Manage. 114, 476-485.

Rees, S.E., Sheehan, E.V., Stewart, B.D., Clark, R., Appleby, T., Attrill, M.J., Jones, P.J., Johnson, D., Bradshaw, N., Pittman, S., 2020. Emerging themes to support ambitious UK marine biodiversity conservation. Mar. Policy, 103864. doi:10.1016/j.marpol.2020.103864.

Rjiba-Bahri, W., Khamassi, F., Kechaou, E.S., Chaffai, A., Souissi, J.B., 2019. Morphological and Biological Traits, Exoskeleton Biochemistry and Socio-Economic Impacts of the Alien Invasive Crab Libinia dubia H. Milne Edwards, 1834 from the Tunisian Coast (Central Mediterranean). Thalassas 35, 291-303. doi:10.1007/s41208-019-0122-5.

Rocklin, D., Levrel, H., Drogou, M., Herfaut, J., Véron, G., 2014. Combining telephone surveys and fishing catches self-report: The French sea bass recreational fishery assessment. PLoS One 9, e87271. doi:10.1371/journal.pone.0087271.

Roy, H.E., Adriaens, T., Aldridge, D., Bacher, S., Bishop, J., Blackburn, T.M., Branquart, E., Brodie, J., Carboneras, C., Cook, E.J., 2015. Invasive Alien Species-Prioritising prevention efforts through horizon scanning: ENV. B. 2/ETU/2014/0016.

Roy, H.E., Peyton, J.M., Booy, O., 2020. Guiding principles for utilizing social influence within expert-elicitation to inform conservation decision-making. Glob. Chang. Biol., doi:10.1111/gcb.15062.

Sala, E., Giakoumi, S., 2017. No-take marine reserves are the most effective protected areas in the ocean. ICES J. Mar. Sci. 75, 1166-1168. doi:https://doi.org/10.1093/icesjms/fsx059.

Savva, I., Chartosia, N., Antoniou, C., Kleitou, P., Georgiou, A., Stern, N., Hadjioannou, L., Jimenez, C., Andreou, V., Hall-Spencer, J.M., 2020. They are here to stay: The biology and ecology of lionfish (Pterois miles) in the Mediterranean Sea. J. Fish Biol., doi:10.1111/jfb.14340.

Saygu, İ., Heymans, J.J., Fox, C.J., Özbilgin, H., Eryaşar, A.R., Gökçe, G., 2020. The importance of alien species to the food web and bottom trawl fisheries of the Northeastern Mediterranean, a modelling approach. J. Mar. Syst. 202, 103253. doi:10.1016/j.jmarsys.2019.103253.

Sbragaglia, V., Correia, R.A., Coco, S., Arlinghaus, R., 2019. Data mining on YouTube reveals fisher group-specific harvesting patterns and social engagement in recreational anglers and spearfishers.

ICES J. Mar. Sci. fsz100. doi:10.1093/icesjms/fsz100.

Schulz, M., Della Vedova, B., 2014. Regulation (EU) No 1143/2014 of the European Parliament and of the Council of 22 October 2014 on the prevention and management of the introduction and spread of invasive alien species. Official Journal of the European Union 317, 35-55.

Seebens, H., Blackburn, T.M., Dyer, E.E., Genovesi, P., Hulme, P.E., Jeschke, J.M., Pagad, S., Pyšek, P., Winter, M., Arianoutsou, M., Bacher, S., Blasius, B., Brundu, G., Capinha, C., Celesti-Grapow, L., Dawson, W., Dullinger, S., Fuentes, N., Jäger, H., Kartesz, J., Kenis, M., Kreft, H., Kühn, I., Lenzner, B., Liebhold, A., Mosena, A., Moser, D., Nishino, M., Pearman, D., Pergl, J., Rabitsch, W., RojasSandolav, J., Roques, A., Rorke, S., Rossinelli, S., Roy, H.E., Scalera, R., Schindler, S., Štajerová, K., Tokarska-Guzik, B., Van Kleunen, M., Walker, K., Weigelt, P., Yamanaka, T., Essl, F., 2017. No saturation in the accumulation of alien species worldwide. Nature communications 8, 1-9. doi:https://doi.org/10.1038/ncomms14435.

Sfriso, A., Buosi, A., Wolf, M.A., Sfriso, A.A., 2020. Invasion of alien macroalgae in the Venice Lagoon, a pest or a resource? Aquat Invasions 15. doi:10.3391/ai.2020.15.2.03

Solandt, J.-L., Mullier, T., Elliott, S., Sheehan, E., 2020. Managing marine protected areas in Europe: moving from 'feature-based'to 'whole-site'management of sites, Marine Protected Areas. Elsevier, pp. $157-181$.

Soyer, B., Leloudas, G., Miller, D., 2018. Tackling IUU fishing: developing a holistic legal response. Transnatl Environ La 7, 139-163. doi:10.1017/S2047102517000267.

Stabili, L., Fraschetti, S., Acquaviva, M.I., Cavallo, R.A., De Pascali, S.A., Fanizzi, F.P., Gerardi, C., Narracci, M., Rizzo, L., 2016. The potential exploitation of the Mediterranean invasive alga Caulerpa cylindracea: can the invasion be transformed into a gain? Mar. Drugs 14, 210.

doi:doi:10.3390/md14110210.

Streftaris, N., Zenetos, A., 2006. Alien marine species in the Mediterranean-the 100 'Worst Invasives' and their impact. Mediterr. Mar. Sci. 7, 87-118. doi:10.12681/mms.180. 
Theodoropoulou, T., 2019. Fishing together, fishing on its own: Fish exploitation patterns at the Neolithic Alepotrypa cave (Diros, Greece) and Aegean prehistoric fishing traditions. Int J Osteoarchaeol 29, 395-406. doi:10.1002/oa.2798.

Tittensor, D.P., Eddy, T.D., Lotze, H.K., Galbraith, E.D., Cheung, W., Barange, M., Blanchard, J.L., Bopp, L., Bryndum-Buchholz, A., Büchner, M., 2018. A protocol for the intercomparison of marine fishery and ecosystem models: Fish-MIP v1. 0. Geoscientific Model Development 11, 1421-1442. Townsend, H., Harvey, C.J., deReynier, Y., Davis, D., Zador, S., Gaichas, S., Weijerman, M., Hazen, E.L., Kaplan, I.C., 2019. Progress on Implementing Ecosystem-Based Fisheries Management in the US Through the Use of Ecosystem Models and Analysis. Frontiers in Marine Science 6, 641.

Trochta, J.T., Pons, M., Rudd, M.B., Krigbaum, M., Tanz, A., Hilborn, R., 2018. Ecosystem-based fisheries management: perception on definitions, implementations, and aspirations. PLoS One 13. doi:10.1371/journal.pone.0190467.

Tsiamis, K., Azzurro, E., Bariche, M., Çinar, M.E., Crocetta, F., De Clerck, O., Galil, B., Gómez, F., Hoffman, R., Jensen, K.R., 2020. Prioritizing marine invasive alien species in the European Union through horizon scanning. Aquat. Conserv.: Mar. Freshwat. Ecosyst. 30. doi:10.1002/aqc.3267. UN, 2019. Special Edition: Progress towards the Sustainable Development Goals Report of the Secretary-General. Advanced unedited version. New York (US): United Nations.

Unal, V., Acarli, D., Gordoa, A., 2010. Characteristics of marine recreational fishing in the anakkale Strait (Turkey). Mediterr. Mar. Sci. 11, 315-330. doi:10.12681/mms.79.

Usseglio, P., Selwyn, J.D., Downey-Wall, A.M., Hogan, J.D., 2017. Effectiveness of removals of the invasive lionfish: how many dives are needed to deplete a reef? PeerJ 5, e3043.

doi:https://doi.org/10.7717/peerj.3043.

van Rijn, I., Kiflawi, M., Belmaker, J., 2019. Alien species stabilize local fisheries catch in a highly invaded ecosystem. Can. J. Fish. Aquat. Sci. 77, 752-761. doi:10.1139/cjfas-2019-0065.

Vitale, R., D'Aniello, E., Gorbi, S., Martella, A., Silvestri, C., Giuliani, M., Fellous, T., Gentile, A., Carbone, M., Cutignano, A., 2018. Fishing for targets of alien metabolites: a novel peroxisome proliferator-activated receptor (PPAR) agonist from a marine pest. Mar. Drugs 16, 431.

doi: $10.3390 / \mathrm{md} 16110431$.

Woodford, D.J., Richardson, D.M., MacIsaac, H.J., Mandrak, N.E., Van Wilgen, B.W., Weyl, O.L., 2016. Confronting the wicked problem of managing biological invasions. NeoBiota 31, 63-86. doi:https://doi.org/10.3897/neobiota.31.10038.

Zenetos, A., Çinar, M.E., Crocetta, F., Golani, D., Rosso, A., Servello, G., Shenkar, N., Turon, X., Verlaque, M., 2017. Uncertainties and validation of alien species catalogues: The Mediterranean as an example. Estuar. Coast. Shelf Sci. 191, 171-187. doi:https://doi.org/10.1016/j.ecss.2017.03.031. 